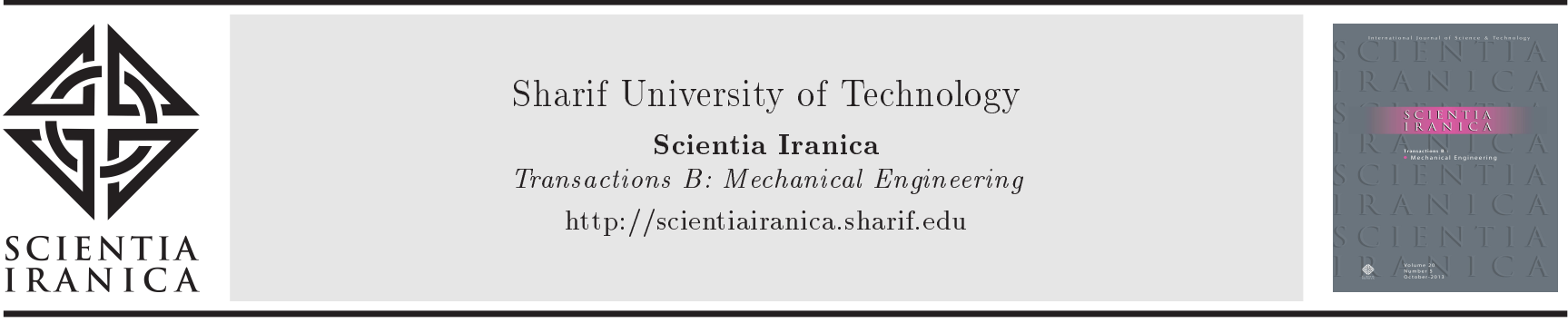

\title{
Computational optimization of a UFAD system using large eddy simulation
}

\author{
R. Rahmaninia, E. Amani*, and A. Abbassi \\ Department of Mechanical Engineering, Amirkabir University of Technology, 424 Hafez Avenue, Tehran, P.O. Box: 15875-4413,
} $\operatorname{Iran.}$

Received 3 October 2018; received in revised form 4 June 2019; accepted 7 July 2019

\author{
KEYWORDS \\ Under-Floor Air \\ Distribution (UFAD); \\ Thermal comfort; \\ Energy saving; \\ Multi-objective \\ optimization; \\ Large Eddy \\ Simulation (LES).
}

\begin{abstract}
In the present study, the Large Eddy Simulation (LES) turbulence closure is applied for the first time, to the best of our knowledge, to investigate the viability of air conditioning systems in a large space. The results of LESs were validated against experimental measurements and the model was used to study the effect of different design variables including Air Changes per Hour ( $\mathrm{ACH})$, supply temperature, and return air vent height on design objectives such as local and global thermal comfort indexes and energysaving parameter by using a systematic multi-objective optimization approach. Sensitivity analysis showed that global and local thermal comfort indexes were highly sensitive to the air supply temperature, while energy saving was sensitive to ACH and the supply temperature to the same extent. In addition, it was found that height of the return air vent affected energy saving more than other factors. Finally, an energy saving rate of $22.9 \%$ along with thermal comfort indexes within the allowable range is achievable by using the best design through the multi-objective optimization.
\end{abstract}

(C) 2020 Sharif University of Technology. All rights reserved.

\section{Introduction}

Nowadays, with the rising population and growing industries around the world, energy consumption crisis compels researchers to seek new ideas in order to manage the growing energy consumption rate of miscellaneous engineering systems, especially buildings. One of the approaches to achieving this goal is using modern ventilation systems. For heating and cooling of spaces, air distribution strategies for conditioning systems significantly affect thermal comfort of the indoor environment and energy costs. Further, they

\footnotetext{
*. Corresponding author. Tel.: +982164543404 E-mail addresses: rahman.r@aut.ac.ir (R. Rahmaninia); eamani@aut.ac.ir (E.Amani); abbassi@aut.ac.ir (A. Abbassi)
}

doi: $10.24200 /$ sci. 2019.51896 .2413 have direct impact on the space organization, interior design, floor height planning, and construction cost [1].

Air distribution systems are divided into three general categories: Mixing Ventilation (MV) [2], Stratum Ventilation (SV), and Displacement Ventilation (DV). Ventilation through Under-Floor Air Distribution (UFAD) is a newly developed DV system that has an impressive effect on the improvement of thermal comfort conditions. A UFAD system can effectively reduce the building life-cycle costs, energy usage, and floor-to-floor height in new constructions and improve the thermal comfort and ventilation efficiency as well as the Indoor Air Quality (IAQ), productivity, and health. However, this system is subject to several drawbacks: being a new and unfamiliar technology, lack of information and design guidelines, perceived higher costs, limited applicability to retrofit construction, and problems with applicable standards and codes [3]. To overcome these issues, studying different aspects of 
UFAD systems has become the main focus of many researchers and engineers using experiments, Computational Fluid Dynamics (CFD), or zonal models.

A summary of the studies performed on UFAD systems using different methods is given in Table 1. These studies have helped engineers answer many questions regarding the use of UFAD systems. Lin et al. $[4,5]$ compared the performances of $\mathrm{MV}$ and DV systems. In another study, Lin et al. [6] showed that supply should be located at the center of the room rather than on the one side of it. Chung et al. [7] and Alajmi and El-Amer [8] indicated that the UFAD system was particularly effective for highceiling buildings. According to previous studies, the vent position has significantly affected the performance of UFAD systems. In addition, except in particular cases, some of the room air must be returned to the ventilation system. However, in most of the previous studies, the return and exhaust air vents have been combined into a single unit. Xu et al. [9] manifested that UFAD systems with separate return and exhaust air vents could lead to a considerable reduction in energy consumption. Fan et al. [10] studied the impact of return vent height in a room served by a UFAD system. Their results showed that by reducing the height of the return vent from the ceiling to floor height, energy saving and $\mathrm{CO}_{2}$ removal increased. However, Lin and Tsai [11] pointed out that the vertical temperature profile remained unaffected by the position of the return air vent. Peng et al. [12] compared Air Carrying Energy Radiant air-conditioning System (ACERS) with the split air conditioner and demonstrated that ACERS could create thermal comfort with small vertical temperature gradients. Cao and Deng [13] investigated the effect of supplied air temperature on IAQ and energy consumption. They concluded that higher supplied air temperatures led to weaker turbulent diffusion and higher levels of indoor $\mathrm{CO}_{2}$ concentration. More examples of studies on UFAD systems are given in Table 1 . In spite of these developments, much more studies are required to reveal different aspects of this new system. Moreover, most of the CFD studies have employed a two-equation $k-\varepsilon$ or $k-\omega$ model for the turbulence closure. Stamou and Katsiris [14] compared different two-equation turbulence closures in a model office room. Their results showed that the computations using the Shear Stress Transport (SST) $k-\omega$ model were in fine agreement with measurements.

The application of more elaborate turbulence closures, e.g., Large Eddy Simulation (LES), to UFAD systems has not been assessed yet. Here, the LES approach to UFAD systems has been applied for the first time, to the best of our knowledge. We validated the model with two sets of experimental databases, namely the new experimental measurements reported in this manuscript and another measurement from the literature. In addition, the knowledge of mutual effects of different design variables including input flow rate, supply temperature, and return air vent height requires a multi-objective optimization study, which has not been performed for a UFAD system yet, to the best of our knowledge. To fill this gap, in this study, a UFAD system is designed following a systematic approach starting with the Design of Experiments (DOEs) technique. Then, the impacts of design variables on objective parameters, esp. the energy saving, are analyzed and after that, through Multi-Objective Optimizations (MOO) [15-17], the best design is proposed. The rest of the paper is organized as follows: the mathematical formulation is introduced in Section 2. The objective parameters including thermal comfort indexes and the energy saving parameter are given in Section 3. The model is validated against experimental data in Section 4 . In Section 5, the results and physical discussions are presented. Finally, the important conclusions of the study are given in Section 6 .

\section{Mathematical model}

In this study, the LES framework was used to account for the flow turbulence closure. In this framework, the governing equations were spatially filtered equations. Here, the governing equations include the mass (continuity), momentum, and energy equations. For a lowMach-number thermally driven flow, these equations can be written as in [31] using the Cartesian tensor notation and summation convention for the repeated indices:

$$
\frac{\partial \rho}{\partial t}+\frac{\partial \rho u_{j}}{\partial x_{j}}=0
$$

where $\rho$ and $u_{j}$ are the density and the $j$ th component of the velocity vector, respectively. All flow properties are filtered quantities. The momentum equation in the $i$ th coordinate direction is given below:

$$
\frac{\partial \rho u_{i}}{\partial t}+\frac{\partial \rho u_{i} u_{j}}{\partial x_{j}}=-\frac{\partial \tilde{p}}{\partial x_{i}}-\frac{\partial \tau_{i j}}{\partial x_{j}}+\rho g_{i},
$$

where $\tilde{p}$ is the modified pressure [32], $g_{i}$ the $i$ th component of the gravitational acceleration vector, and $\tau_{i j}$ the total stress tensor modeled by a gradient diffusion assumption here:

$$
\begin{aligned}
\tau_{i j} & =-2\left(\mu+\mu_{t}\right)\left[S_{i j}-\frac{1}{3} \frac{\partial u_{k}}{\partial x_{k}} \delta_{i j}\right], \\
S_{i j} & =\frac{1}{2}\left(\frac{\partial u_{i}}{\partial x_{j}}+\frac{\partial u_{j}}{\partial x_{i}}\right),
\end{aligned}
$$

and $\mu$ is the molecular dynamic viscosity. In an LES framework, the turbulent viscosity, $\mu_{t}$, is modeled by 
Table 1. A summary of recent studies performed on Under-Floor Air Distribution (UFAD) systems during the last decade.

\begin{tabular}{|c|c|c|c|c|}
\hline $\begin{array}{c}\text { Authors } \\
\text { (year) }\end{array}$ & $\begin{array}{c}\text { Design } \\
\text { parameters }\end{array}$ & $\begin{array}{c}\text { Objective } \\
\text { parameters }\end{array}$ & Method & Findings \\
\hline $\begin{array}{l}\text { Shan et al. } \\
(2019)[18]\end{array}$ & $\begin{array}{l}\text { Supply air } \\
\text { temperature } \\
\text { and velocity, } \\
\text { radiant } \\
\text { temperature }\end{array}$ & $\begin{array}{l}\text { Thermal comfort } \\
(\mathrm{PMV})\end{array}$ & $\begin{array}{l}\text { Experiment/CFD } \\
(\mathrm{RNG} k-\varepsilon)\end{array}$ & $\begin{array}{l}\text { The velocity values are below the draft sensation } \\
\text { limitations. The distribution of PMV shows } \\
\text { the fan coil unit is capable of } \\
\text { providing thermally comfortable conditions. }\end{array}$ \\
\hline $\begin{array}{l}\text { Ahmed and Gao } \\
(2017)[19]\end{array}$ & $\begin{array}{l}\text { Exhaust } \\
\text { vent height }\end{array}$ & $\begin{array}{l}\text { Energy saving, } \\
\text { thermal comfort, } \\
\text { draught risk, IAQ }\end{array}$ & $\begin{array}{l}\text { CFD (RNG } \\
k-\varepsilon)\end{array}$ & $\begin{array}{l}\text { For a case with the } 1.6 \mathrm{~m} \text { combined exhaust } \\
\text { height, the optimal performance was achieved } \\
\text { (energy savings up to } 22.56 \% \text { and inhaled } \\
\text { air quality improvement). }\end{array}$ \\
\hline $\begin{array}{l}\text { Fan et al. } \\
(2017)[10]\end{array}$ & $\begin{array}{l}\text { Return vent } \\
\text { height }\end{array}$ & $\begin{array}{l}\text { Thermal comfort, } \\
\text { IAQ, contaminant } \\
\text { removal energy } \\
\text { saving }\end{array}$ & $\begin{array}{l}\mathrm{CFD} \\
(\mathrm{RNG} k-\varepsilon)\end{array}$ & $\begin{array}{l}\text { Energy saving was increased by reducing } \\
\text { the height of the return vent from the } \\
\text { ceiling to floor height. A descending } \\
\text { return vent resulted in a lower } \mathrm{CO}_{2} \\
\text { concentration but a larger mean age of air. }\end{array}$ \\
\hline $\begin{array}{l}\text { Zhang et al. } \\
(2016)[20]\end{array}$ & $\begin{array}{l}\text { Supply air } \\
\text { temperature, } \\
\text { airflow rate, } \\
\text { number and } \\
\text { type of } \\
\text { diffusers }\end{array}$ & $\begin{array}{l}\text { Temperature } \\
\text { distribution }\end{array}$ & Experiment & $\begin{array}{l}\text { The large-area grille diffusers, } \\
\text { as an alternative choice, } \\
\text { can create stratification comparable } \\
\text { to the more conventional swirl diffusers. }\end{array}$ \\
\hline $\begin{array}{l}\text { Nada et al. } \\
(2016)[21]\end{array}$ & $\begin{array}{l}\text { Supply air } \\
\text { temperature } \\
\text { and velocity, } \\
\text { number of } \\
\text { diffusers, } \\
\text { space height }\end{array}$ & $\begin{array}{l}\text { Airflow pattern, } \\
\text { temperature } \\
\text { distribution, } \\
\text { thermal comfort }\end{array}$ & $\begin{array}{l}\text { CFD } \\
\text { (realizable } \\
k-\varepsilon)\end{array}$ & $\begin{array}{l}\text { UFAD system is capable of creating } \\
\text { smaller vertical air temperature } \\
\text { gradients than Over Head Air } \\
\text { Distribution (OHAD) system. } \\
\text { The optimum performance obtained } \\
\text { at } 18^{\circ} \mathrm{C} \text { supply air temperature, } \\
0.8 \mathrm{~m} / \mathrm{s} \text { supply air velocity, } \\
\text { and proper number and distribution } \\
\text { of supply diffusers for a large theatre. }\end{array}$ \\
\hline $\begin{array}{l}\text { Alajmi et al. } \\
(2015)[22]\end{array}$ & $\begin{array}{l}\text { Supply air } \\
\text { temperature } \\
\text { and velocity }\end{array}$ & $\begin{array}{l}\text { Thermal comfort, } \\
\text { temperature } \\
\text { distribution }\end{array}$ & $\begin{array}{l}\text { Experiment } \\
\text { CFD (standard } \\
k-\varepsilon \text { ) }\end{array}$ & $\begin{array}{l}\text { The Predicted Mean Vote (PMV) } \\
\text { was misleading, whereas the Air } \\
\text { Distribution Performance Index (ADPI) } \\
\text { was more indicative of the relative } \\
\text { level of occupants' thermal comfort. }\end{array}$ \\
\hline $\begin{array}{l}\text { Alajmi et al. } \\
(2015)[22]\end{array}$ & $\begin{array}{l}\text { Supply air } \\
\text { temperature } \\
\text { and velocity }\end{array}$ & $\begin{array}{l}\text { Thermal comfort, } \\
\text { temperature } \\
\text { distribution }\end{array}$ & $\begin{array}{l}\text { Experiment/CFD } \\
\text { (standard } k-\varepsilon \text { ) }\end{array}$ & $\begin{array}{l}\text { The Predicted Mean Vote (PMV) was misleading, } \\
\text { whereas the Air Distribution Performance } \\
\text { Index (ADPI) was more indicative of } \\
\text { the relative level of occupants' } \\
\text { thermal comfort. }\end{array}$ \\
\hline
\end{tabular}


Table 1. A summary of recent studies performed on Under-Floor Air Distribution (UFAD) systems during the last decade (continued).

\begin{tabular}{|c|c|c|c|c|}
\hline $\begin{array}{c}\text { Authors } \\
\text { (year) }\end{array}$ & $\begin{array}{c}\text { Design } \\
\text { parameters }\end{array}$ & $\begin{array}{c}\text { Objective } \\
\text { parameters }\end{array}$ & Method & Findings \\
\hline $\begin{array}{l}\text { Lin and Tsai } \\
(2014)[11]\end{array}$ & $\begin{array}{l}\text { Supply air } \\
\text { flow rate }\end{array}$ & $\begin{array}{l}\text { Vertical } \\
\text { temperature } \\
\text { profile }\end{array}$ & Experiment & $\begin{array}{l}\text { When the supply air flow rate increases for } \\
\text { a given diffuser, the vertical } \\
\text { temperature gradient becomes milder } \\
\text { and the indoor air stratification } \\
\text { decreases. The vertical temperature } \\
\text { profile seems unaffected by the change in } \\
\text { the position of return air vent. }\end{array}$ \\
\hline $\begin{array}{l}\text { Alajmi et al. } \\
(2013)[23]\end{array}$ & $\begin{array}{l}\text { Supply air } \\
\text { temperature }\end{array}$ & $\begin{array}{l}\text { Energy } \\
\text { saving }\end{array}$ & Experiment & $\begin{array}{l}\text { The thermal stratification establishment } \\
\text { is the key factor in efficient } \\
\text { operation of UFAD system. }\end{array}$ \\
\hline $\begin{array}{l}\text { Kim et al. } \\
(2013)[24]\end{array}$ & $\begin{array}{l}\text { Supply air } \\
\text { velocity and } \\
\text { temperature, } \\
\text { location of } \\
\text { diffusers }\end{array}$ & $\begin{array}{l}\text { Thermal } \\
\text { comfort }\end{array}$ & $\begin{array}{l}\mathrm{CFD} \\
(k-\varepsilon)\end{array}$ & $\begin{array}{l}\text { The location of the diffusers plays } \\
\text { a key role in the maximum change in airflow } \\
\text { in a huge theater space with a high ceiling. }\end{array}$ \\
\hline $\begin{array}{l}\text { Fong et al. } \\
(2011)[25]\end{array}$ & $\begin{array}{l}\text { Supply air } \\
\text { flow rate, } \\
\text { room temperature, } \\
\text { relative humidity, } \\
\text { ventilation methods }\end{array}$ & $\begin{array}{l}\text { Thermal } \\
\text { comfort, } \\
\text { energy saving }\end{array}$ & Experiment & $\begin{array}{l}\text { SV, DV, and MV systems were compared. } \\
\text { SV could provide satisfactory thermal } \\
\text { comfort level to rooms of temperature } \\
\text { up to } 27^{\circ} \mathrm{C} \text {. }\end{array}$ \\
\hline $\begin{array}{l}\text { Chung et al. } \\
(2010)[7]\end{array}$ & $\begin{array}{l}\text { Mean radiant } \\
\text { temperature }\end{array}$ & $\begin{array}{l}\text { Thermal } \\
\text { comfort, air } \\
\text { temperature } \\
\text { distribution }\end{array}$ & $\begin{array}{l}\mathrm{CFD} \\
(k-\varepsilon)\end{array}$ & $\begin{array}{l}\text { UFAD systems offer significant energy } \\
\text { savings with respect to traditional } \\
\text { OHAD systems, esp. for high ceiling } \\
\text { height buildings. }\end{array}$ \\
\hline $\begin{array}{l}\text { Alajmi and } \\
\text { El-Amer } \\
(2010)[8]\end{array}$ & $\begin{array}{l}\text { Air supply } \\
\text { temperature }\end{array}$ & $\begin{array}{l}\text { Thermal comfort, } \\
\text { energy } \\
\text { consumption }\end{array}$ & Zonal & $\begin{array}{l}\text { UFAD systems, compared to MV } \\
\text { systems, consume less energy } \\
\text { (about } 30 \% \text { for high-celling-type buildings). }\end{array}$ \\
\hline $\begin{array}{l}\text { Xu et al. } \\
(2009)[9]\end{array}$ & $\begin{array}{l}\text { Internal } \\
\text { heat sources } \\
\text { and return air } \\
\text { vent position }\end{array}$ & $\begin{array}{l}\text { Energy } \\
\text { consumption }\end{array}$ & $\begin{array}{l}\text { CFD (standard } \\
k-\varepsilon)\end{array}$ & $\begin{array}{l}\text { UFAD systems with separate return } \\
\text { and exhaust air vents can lead } \\
\text { to an energy consumption reduction. }\end{array}$ \\
\hline $\begin{array}{l}\text { Lin et al. } \\
(2009)[26]\end{array}$ & $\begin{array}{l}\text { Internal } \\
\text { partitions }\end{array}$ & 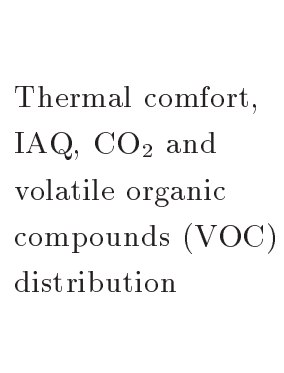 & $\begin{array}{l}\text { CFD (RNG } \\
k-\varepsilon)\end{array}$ & $\begin{array}{l}\text { The thermal comfort is improved by } \\
\text { the introduction of the partial partition. } \\
\text { The presence of a gap above the partition } \\
\text { walls improves the air distribution } \\
\text { by reducing the re-circulation. } \\
\text { The UFAD system may not be effective in } \\
\text { situations where ground level contaminants } \\
\text { are the main source of pollutants. }\end{array}$ \\
\hline
\end{tabular}


Table 1. A summary of recent studies performed on Under-Floor Air Distribution (UFAD) systems during the last decade (continued).

\begin{tabular}{|c|c|c|c|c|}
\hline $\begin{array}{c}\text { Authors } \\
\text { (year) }\end{array}$ & $\begin{array}{c}\text { Design } \\
\text { parameters }\end{array}$ & $\begin{array}{c}\text { Objective } \\
\text { parameters }\end{array}$ & Method & Findings \\
\hline $\begin{array}{l}\text { Awad et al. } \\
(2008)[27]\end{array}$ & $\begin{array}{l}\text { Air supply and } \\
\text { exhaust location }\end{array}$ & $\begin{array}{l}\text { Vertical } \\
\text { temperature } \\
\text { profiles }\end{array}$ & Experiment & $\begin{array}{l}\text { The relative importance of inertial } \\
\text { (momentum flux) and buoyant forces } \\
\text { determines the position of the } \\
\text { interface and level of stratification. } \\
\text { The formation of a stratified region } \\
\text { near the ceiling acts as an insulation } \\
\text { reducing the cooling load. }\end{array}$ \\
\hline $\begin{array}{l}\text { Stamou and } \\
\text { Katsiris } \\
(2006)[14]\end{array}$ & $\begin{array}{l}\text { Turbulence models } \\
\text { (SST } k-\omega, \\
\text { standard } k-\varepsilon \\
\text { RNG } k-\varepsilon \\
\text { and laminar model) }\end{array}$ & $\begin{array}{l}\text { Air flow } \\
\text { velocity and } \\
\text { temperature } \\
\text { distributions }\end{array}$ & CFD & $\begin{array}{l}\text { Computations with the SST } \\
k-\omega \text { model showed } \\
\text { the best agreement with the } \\
\text { measurements. }\end{array}$ \\
\hline $\begin{array}{l}\text { Lin et al. } \\
(2005)[5]\end{array}$ & $\begin{array}{l}\text { Air supply and } \\
\text { exhaust location }\end{array}$ & $\begin{array}{l}\text { Thermal } \\
\text { comfort, IAQ }\end{array}$ & $\begin{array}{l}\text { CFD (RNG } \\
k-\varepsilon)\end{array}$ & $\begin{array}{l}\text { The supply should be located near the } \\
\text { center rather than on the one side of the } \\
\text { room. The exhaust location was found } \\
\text { to have a minor effect on the thermal comfort. }\end{array}$ \\
\hline $\begin{array}{l}\text { Lin and } \\
\text { Linden } \\
(2005)[28]\end{array}$ & $\begin{array}{l}\text { Heat load, } \\
\text { ventilation rate, } \\
\text { momentum flux }\end{array}$ & Flow pattern & $\begin{array}{l}\text { Experiment } \\
\text { and theory }\end{array}$ & $\begin{array}{l}\text { A new UFAD theoretical model was } \\
\text { developed and validated with } \\
\text { the experiment. }\end{array}$ \\
\hline $\begin{array}{l}\text { Wan and } \\
\text { Chao (2005) [29] }\end{array}$ & $\begin{array}{l}\text { Return air vent } \\
\text { position and } \\
\text { supply temperature }\end{array}$ & $\begin{array}{l}\text { Airflow and } \\
\text { temperature } \\
\text { distributions }\end{array}$ & $\begin{array}{l}\text { Experiment } \\
\text { and CFD } \\
\text { (standard } \\
k-\varepsilon \text { ) }\end{array}$ & $\begin{array}{l}\text { When the thermal length scale, which } \\
\text { is defined based on the jet momentum and } \\
\text { buoyancy fluxes [30], of the supply jets } \\
\text { was large, the temperature } \\
\text { stratification became significant. } \\
\text { Air existing at the floor level produced } \\
\text { larger stratification than } \\
\text { that existing at the ceiling level. }\end{array}$ \\
\hline $\begin{array}{l}\text { Lin et al. } \\
(2005)[5]\end{array}$ & $\begin{array}{l}\text { System type } \\
\text { (MV and DV) }\end{array}$ & $\begin{array}{l}\text { Thermal } \\
\text { comfort, } \\
\text { IAQ }\end{array}$ & $\begin{array}{l}\text { CFD (RNG } \\
k-\varepsilon)\end{array}$ & $\begin{array}{l}\text { Through a proper design, } \\
\text { DV can maintain a thermally } \\
\text { comfortable environment } \\
\text { with a better IAQ, especially } \\
\text { for the breathing zone. }\end{array}$ \\
\hline
\end{tabular}

a Sub Grid-Scale (SGS) turbulence closure. Here, Deardorff's model [33] is used as follows:

$$
\begin{aligned}
& \mu_{t}=\rho C_{v} \Delta \sqrt{k_{s g s}}, \\
& k_{s g s}=\frac{1}{2}\left((u-\hat{u})^{2}+(v-\hat{v})^{2}+(w-\hat{w})^{2}\right),
\end{aligned}
$$

where $\Delta$ is the local filter width and $\hat{u}$ is the weighted average of $u$ over the adjacent cells (representing a testfiltered field on a length scale of $2 \Delta$ ). Here, the implicit filter (i.e., computational grid) is used and the filter width is considered as:

$$
\Delta=(\Delta x \Delta y \Delta z)^{1 / 3},
$$

where $\Delta x, \Delta y$, and $\Delta z$ are grid spacings in three spatial directions. The model constant is $C_{v}=0.1$ 
[32]. This constant value of $C_{v}$ does not result in the correct limiting value of the turbulent viscosity near the walls. To account for this deficiency, Van Driest's damping function [34] is applied to compute $\mu_{t}$ near wall boundaries.

The energy equation is given as follows:

$$
\begin{gathered}
\frac{\partial}{\partial t}\left(\rho h_{s}\right)+\frac{\partial}{\partial x_{j}}\left(\rho h_{s} u_{j}\right)=\frac{D p}{D t}+\frac{\partial}{\partial x_{j}} \\
{\left[\left(k+\frac{\mu_{t} C_{p}}{\operatorname{Pr}_{t}}\right) \frac{\partial T}{\partial x_{j}}\right],}
\end{gathered}
$$

where $h_{s}, T$, and $p$ are sensible enthalpy, temperature, and (background) pressure, respectively, and $C_{p}$ and $k$ are the specific heat capacity at constant pressure and thermal conductivity. Here, the standard wall functions [31] for the velocity and temperature are used for the wall boundaries. To close the governing equations, the ideal gas relation is as follows:

$$
p=\frac{\rho R T}{\bar{W}}
$$

and the NIST-JANAF tables [35] (the sensible enthalpy versus temperature) are added to the set of equations mentioned above. Note that $R$ and $\bar{W}$ are the universal gas constant and air molecular weight, respectively.

\section{Objective parameters}

In this section, the objective parameters quantifying the thermal comfort are introduced. These parameters are calculated from the flow fields, i.e., the CFD solution of the governing equations discussed in Section 2 .

The first objective is Fanger's Predicted Mean Vote (PMV) index [36]. According to ISO7730 standard, for the thermal comfort, the average PMV over the occupant zone should be between 0.5 and +0.5 [37]. Sometimes, the Predicted Percentage of Dissatisfied (PPD) index [37], which is a function of PMV, is used instead. According to ISO7730 standard, the proper value of this index is between 0 and $15 \%$ [37].

As mentioned above, the global thermal comfort indexes, e.g., PMV or PPD, should be within the allowable range [37]. However, this is a necessary, yet sufficient, condition to achieve thermal comfort and it is probable for some occupants to feel a sense of discomfort in some parts of their bodies. This is called local thermal discomfort [38], which can be quantified by several parameters. One of the main causes of the local thermal discomfort is the environment Temperature Gradient in Vertical Direction (TGVD). This parameter is defined as the air temperature difference between the positions of an occupant head and ankle. According to ISO7730 standard, TGVD should not exceed $3^{\circ} \mathrm{C}$. The use of UFAD system can cause the air draft near the occupants' bodies and local thermal discomfort. The American Society of Heating, Refrigerating and Air-conditioning Engineers (ASHRAE) advocates that to avoid local thermal discomfort, the mean air velocity within the occupant zone, $V_{M E A N}$, should be less than $0.8(\mathrm{~m} / \mathrm{s})[38]$.

Cheng et al. [39] found that the application of UFAD systems reduced the cooling coil load, compared to MV systems. The ratio of the cooling load energy reduction to the total space cooling load, which is called energy saving, is calculated by:

$$
E_{r}=\frac{\dot{m}_{e} C_{p}\left(T_{e}-T_{\text {set }}\right)}{Q_{\text {space }}} \times 100 \%,
$$

where $Q_{\text {space }}$ is the space cooling load and is calculated by:

$$
Q_{\text {space }}=\dot{m}_{e} C_{p}\left(T_{e}-T_{\text {set }}\right)+\dot{m}_{r} C_{p}\left(T_{r}-T_{\text {set }}\right),
$$

and $T_{e}$ is the exhaust air temperature, $T_{r}$ the return air temperature, $T_{\text {set }}$ the set-point air temperature considered as the average air temperature in the range of $0.8 \mathrm{~m}$ to $1.2 \mathrm{~m}$ from floor for UFAD systems, $\dot{m}_{e}$ the exhaust air flow rate, and $\dot{m}_{r}$ the return air flow rate.

\section{Numerical method}

The governing equations (in Section 2) were solved using finite difference discretization. Here, the standard 2nd-order central differencing scheme was applied to the diffusion terms and the 2 nd-order fully conservative central differencing scheme, with both momentum and kinetic energy conservative properties, in conjunction with Superbee flux limiter [40] (to preserve the monotonicity) was incorporated in convection terms. An explicit predictor-corrector method [31] was used to decouple the governing equations, which resulted in the second-order temporal accuracy. The CourantFriedrichs-Lewy (CFL) condition, $\mathrm{CFL}<1$, was considered for the variable time step approach used in the computations. The numerical solutions were obtained using fire dynamics simulator (version 6.5.1) [41] opensource software.

To validate the mathematical model and numerical method, a room with a displacement system experimentally studied by Loomans [42] was considered in this section. This room with dimensions of $5.16 \mathrm{~m}$ (length), $3.65 \mathrm{~m}$ (width), and $2.5 \mathrm{~m}$ (height) is shown in Figure 1. The total air change rate and the air supply temperature were $0.047 \mathrm{~m}^{3} / \mathrm{s}$ and $19.8^{\circ} \mathrm{C}$, respectively. The inflow boundary condition with a uniform velocity and temperature was assumed at the supply grille. The Neumann (zero-gradient) boundary condition was used for the outflow on the exhaust and no-slip boundary on the other surfaces. Heats emitting from each fluorescent lamp, computer, and reading light were 


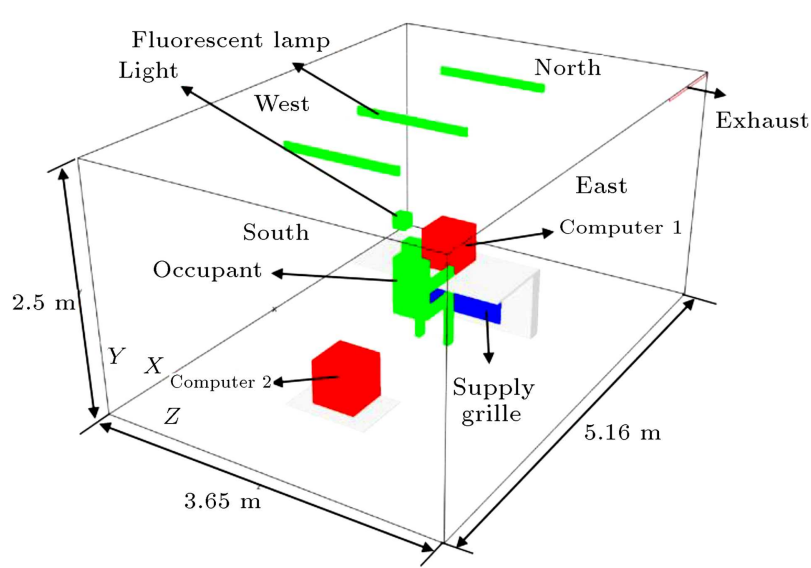

Figure 1. The configuration of the room used for the model validation. The coordinate system is shown in the lower left corner.

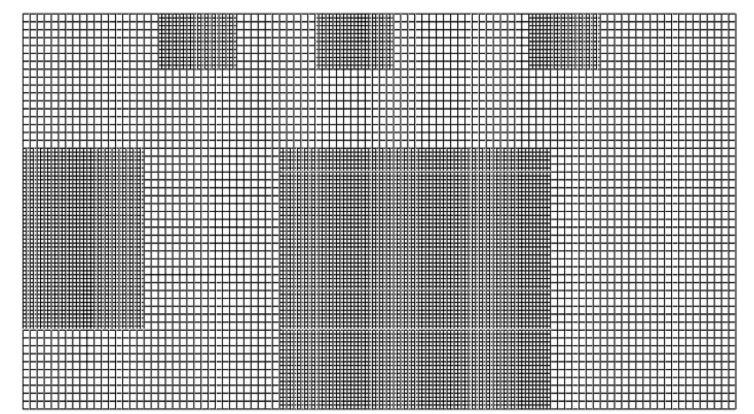

Figure 2. The computational grid for the validation case on the central XY plane $(Z=1.825 \mathrm{~m})$.

set to $64.4,98.4$, and $27.9 \mathrm{~W}$, respectively. A hollow block was used as the occupant with the surface equal to $1.6 \mathrm{~m}^{2}$ and $104.7 \mathrm{~W}$ heat outputs. The uniform heat flux boundary conditions were applied to the surface of all of these objects generating heat. The zero heat flux was applied to the walls of the desk and constant temperature boundary conditions at the room boundaries, which are presented in Table 2 .

For this problem, a block-structured grid with 1.23 million computational cells was generated. The grid spacing within each block was uniform, but the blocks were devised such that the grid near the objects, heat sources, and supply air diffuser was finer, as can be seen in Figure 2. The results of the present LES

Table 2. Wall boundary temperatures of the validation case [42].

\begin{tabular}{cc}
\hline Wall & Temperature $\left({ }^{\circ} \mathbf{C}\right)$ \\
\hline Floor & 22.2 \\
Ceiling & 22.3 \\
North & 22.7 \\
South & 22.6 \\
East & 22.8 \\
West & 23.2 \\
\hline
\end{tabular}

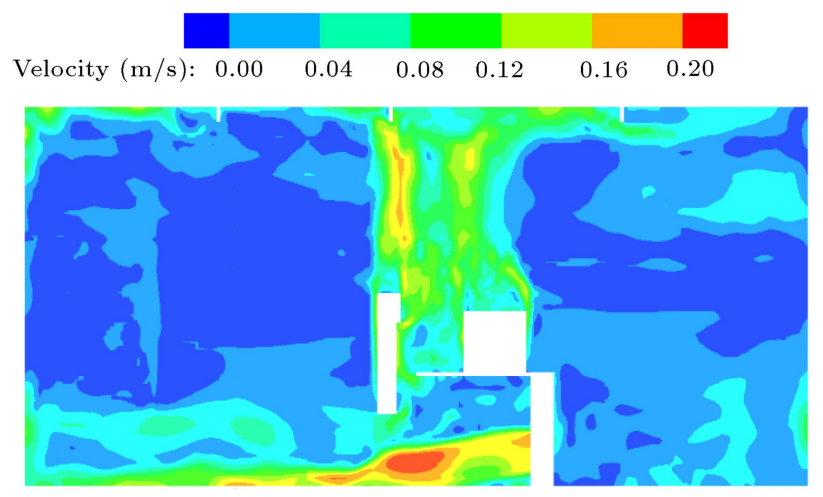

(a)

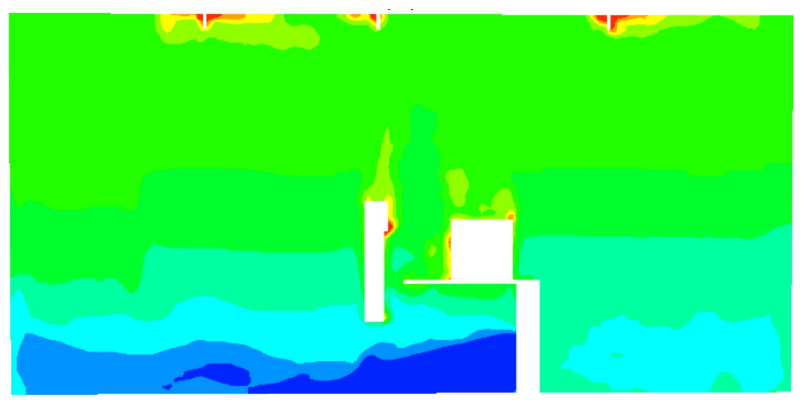

(b)

Figure 3. Present simulation of the validation case: (a) Velocity and (b) temperature contours on the central XY plane.

are shown in Figure 3. The forced flow from the inlet diffuser grille under the desk and the natural convection over the occupant and computer are clearly observable in the computed velocity field (Figure 3(a)). The stratified temperature field generated by the DV system is also observed in Figure 3(b). The filtered fields obtained by LES were instantaneous quantities oscillating in time. To obtain mean temperature or velocity fields, a time averaging procedure was adopted. For the present case, the simulations were conducted for $400 \mathrm{~s}$ to reach a statistically stationary condition. Then, the time-averaged statistics were computed by continuing the simulation between 400$600 \mathrm{~s}$ and collecting the results at a frequency rate of 0.1 s, i.e., 2000 samples of the fields. To ensure the proper choice of the start (stationary state) and duration of the run-time averaging procedure, two different choices were tested and the results of the mean velocity and temperature profiles were compared, as shown in Figure 4. This comparison ensures that the stationary state and run-time averaging duration were chosen large enough for the mean statistics to be independent of these numerical parameters. This check was done for all simulations performed in this study. In Figure 5 , the temperature profiles of the present simulation are compared with the experimental data [42]. The agreement between the simulation and measurement validates the accuracy of our modeling approach. 


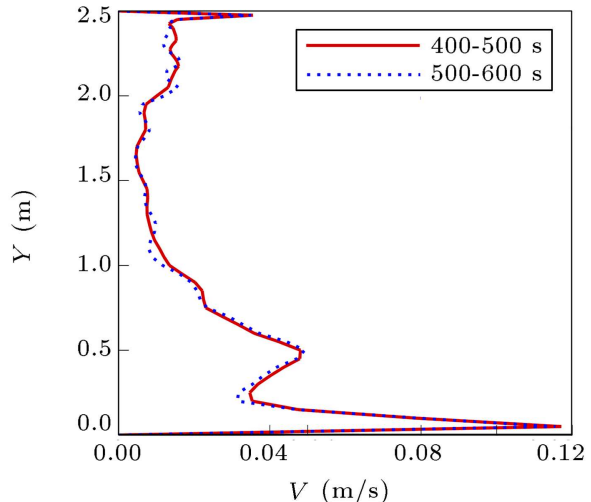

(a)

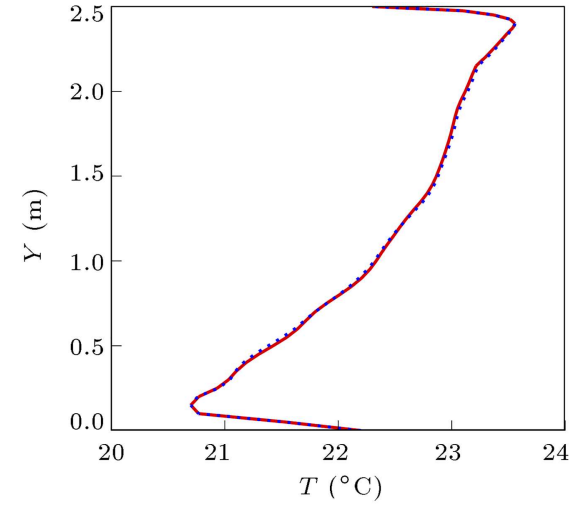

(b)

Figure 4. The comparison of the computed mean profiles along the vertical lines $(x=1.5 \mathrm{~m}, z=1.93 \mathrm{~m})$ for two different choices of the start and duration of the run-time averaging: (a) Mean velocity and (b) mean temperature.

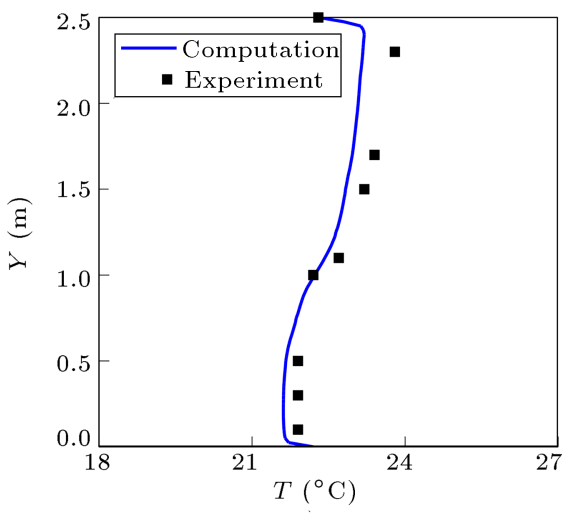

(a)

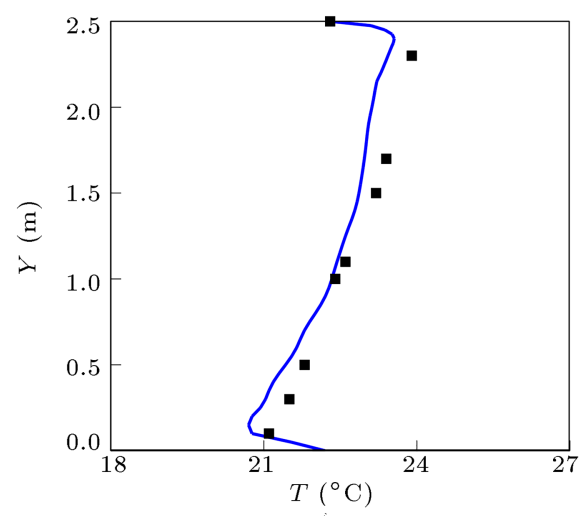

(b)

Figure 5. The comparison of the experimental [42] and present computed air temperature profiles along the vertical lines: (a) $x=3.75 \mathrm{~m}, z=1.93 \mathrm{~m}$, (b) $x=1.5 \mathrm{~m}$ and $z=1.93 \mathrm{~m}$.

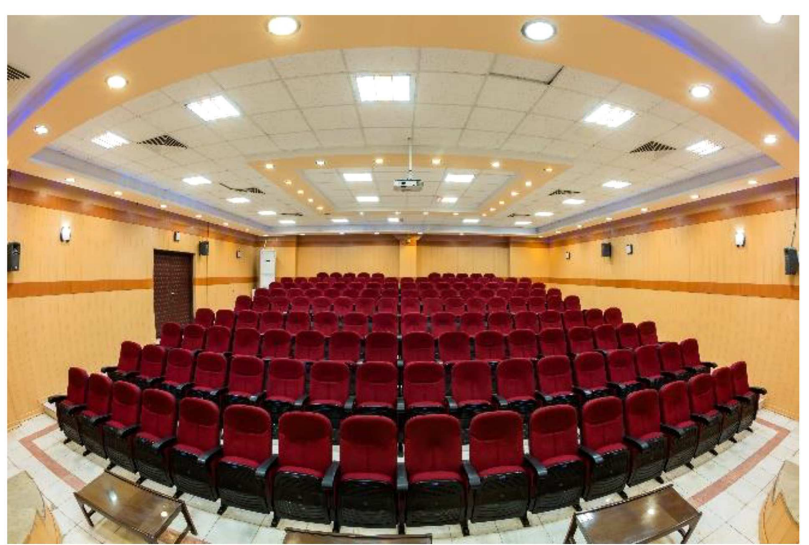

(a)

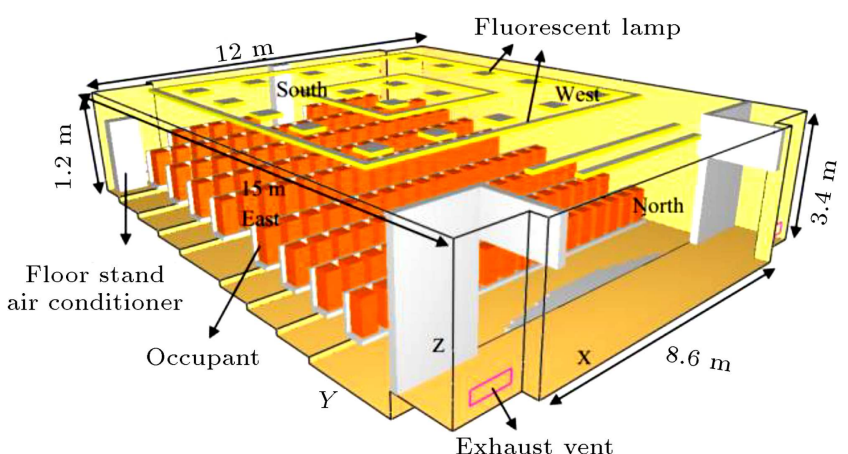

(b)

Figure 6. The configuration of the amphitheater studied in this work: (a) A photo of the amphitheater and (b) the computational domain.

\section{Results and discussion}

\subsection{Main case study: Experimental versus LES results}

The main case study of this work is an amphitheater, located in Central Amphitheatre of Amirkabir
University of Technology, with 146 occupants. This amphitheater is shown in Figure 6 and is of $15 \mathrm{~m}$ length, $12 \mathrm{~m}$ width, and $4 \mathrm{~m}$ height (Figure 6(b)). To perform preliminary tests, before constructing the main UFAD ventilation system, a floor standing air conditioner was placed in the south-east corner of the 

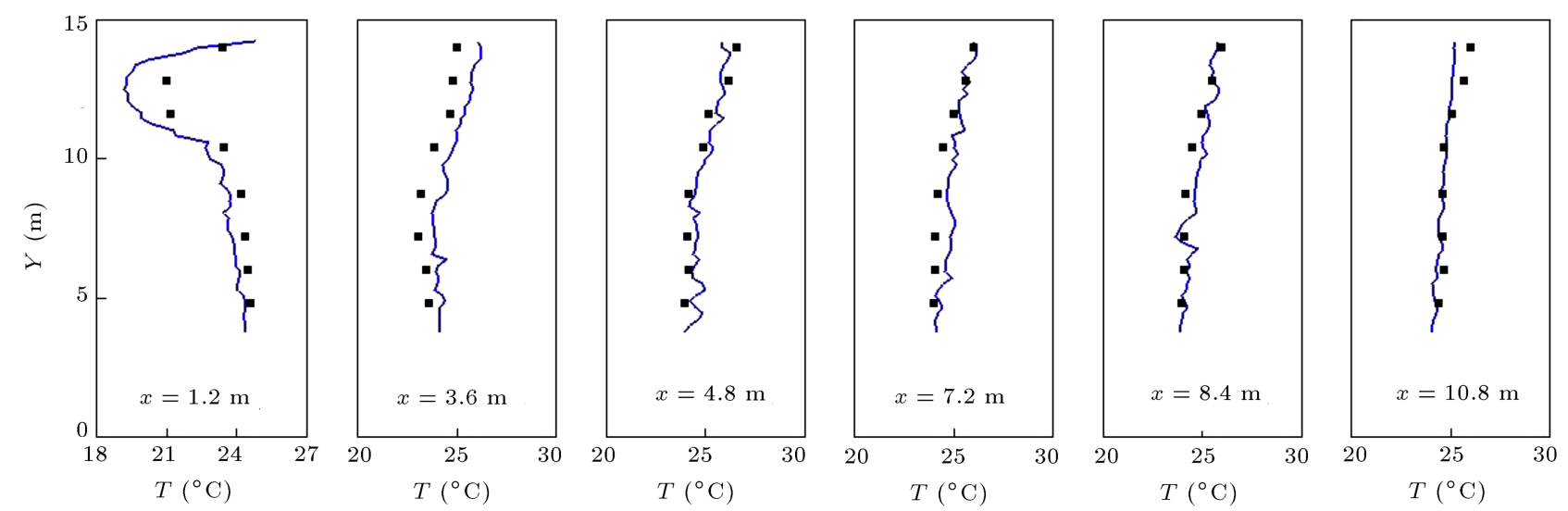

Figure 7. The comparison of the present experimental and computational air temperature profiles for the main case study (amphitheater) at $z=1.5 \mathrm{~m}$ from the floor at different $x$ directions. The symbols are present experimental measurements and the blue lines are present computation.

Table 3. The wall temperatures of the amphitheater.

\begin{tabular}{cc}
\hline Wall & Temperature $\left({ }^{\circ} \mathbf{C}\right)$ \\
\hline Floor & 23.9 \\
Ceiling & 25.1 \\
North & 24.6 \\
South & 24.1 \\
East & 24.7 \\
West & 24.3 \\
\hline
\end{tabular}

amphitheater. Two exhaust vents were on the bottom corners of the north wall. The volumetric flow rate and the air supply temperature for the floor standing air conditioner were $0.47 \mathrm{~m}^{3} / \mathrm{s}$ and $19^{\circ} \mathrm{C}$, respectively. The heats emitting from each occupant and fluorescent lamp were $75 \mathrm{~W}$ and $45 \mathrm{~W}$, respectively. The measured mean temperature of different walls is shown in Table 3. The wall temperature measurements were carried out by an Infrared Thermometer device with the accuracy of $\pm 0.2 \%$.

For the present amphitheater, the air temperature measurements were conducted at a distance of $1.5 \mathrm{~m}$ from the floor and in 6 different sections. For measuring the air temperature and relative humidity of the environment, Testo 605-H1 device with the accuracy of $\pm 3 \%$ was used. The results of the measurements are reported in Figure 7.

The proposed case was simulated using the LESCFD model introduced in Section 2 and validated in Section 4. The computational domain of this simulation is shown in Figure 6(b) for which a blockstructured computational grid with 23 blocks and 3.41 million cells is constructed (see Figure 8). The blocks were arranged to have finer grids in areas with higher gradients near the inlet, exhaust vents, occupied zone, and lamps. The simulation was performed for $400 \mathrm{~s}$ to reach the statistically stationary state and then,

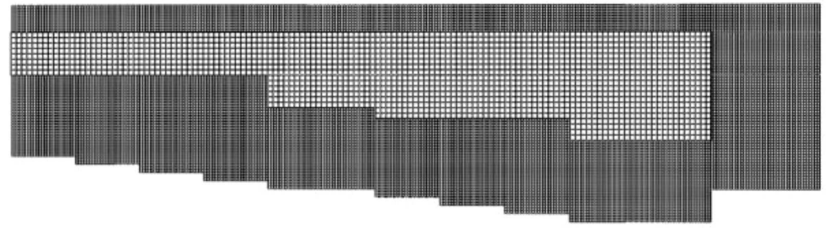

Figure 8. The computational grid used for the amphitheater problem on the plane $x=6 \mathrm{~m}$.

the time-averaged quantities were computed during additional $200 \mathrm{~s}$ (from $400 \mathrm{~s}$ to $600 \mathrm{~s}$ ). The computational time of each simulation of the amphitheater was about 36 hours on the workstation system at high performance computing research center. The code was parallelized on $12 \mathrm{CPUs}(2.3 \mathrm{GHz}, 12 \mathrm{MB}$ Cache, 16 GB RAM).

The results of the simulation were compared with the experimental measurements, as shown in Figure 7. The overall agreement is satisfactory, but there are deviations between the experimental data and LES in some regions. The main cause of deviations can be the assumption of constant wall temperature for the large walls of the amphitheater and the measurement uncertainties. Note that the heat generated by the floor standing air conditioner was neglected in this single simulation. This could be the reason for slight underprediction of the temperature profile near the air conditioner in the section $x=1.2 \mathrm{~m}$ within $12.0<y<$ $14.0 \mathrm{~m}$.

\subsection{Design and optimization of a UFAD system}

In this section, a UFAD system is designed and optimized for the amphitheater introduced in the previous section using a computational optimization approach based on the LES model developed in the previous sections. A sample design of the UFAD ventilation system for the amphitheater is shown in Figure 9 as 


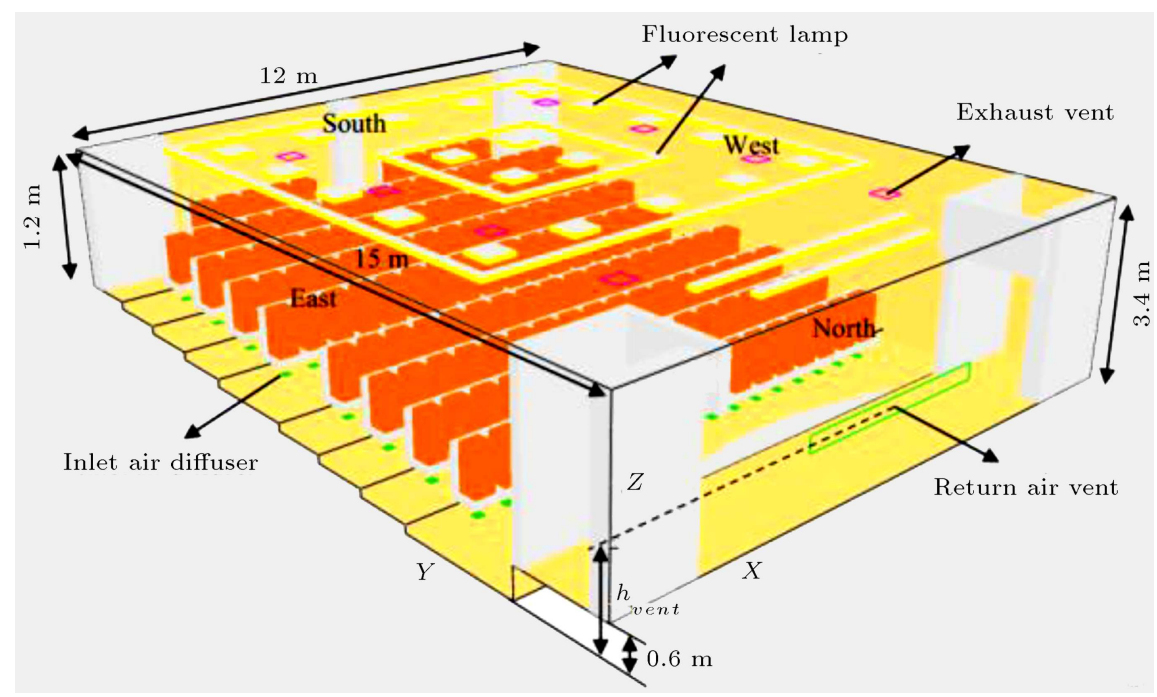

Figure 9. The configuration of the amphitheater equipped with a Under-Floor Air Distribution (UFAD) system.

the base case. According to this figure, 146 direct inlet diffusers $\left(0.2 \times 0.2 \mathrm{~m}^{2}\right)$ located at the floor elevation under the occupant seats, a return air vent $\left(4 \times 0.3 \mathrm{~m}^{2}\right)$ located on the north wall, and 8 exhaust vents $(0.4 \times$ $0.4 \mathrm{~m}^{2}$ ) located at the ceiling elevation in two rows are placed in the computational domain. Note that the purpose of considering a return air vent is to save energy, according to Eq. (8).

Other important design parameters of the UFAD system are the Air Change per Hour (ACH), supply temperature, $T_{\text {sup }}$, and return air vent height, $h_{\text {vent }}$. These parameters were selected using computational multi-objective optimization in the next section. In addition, this approach makes it possible to study the effect of the design parameters on the desired objectives systematically.

The boundary conditions for the simulations are as follows: the inflow boundary condition with the uniform temperature of $T_{\text {sup }}$ and the uniform velocity of $A C H \times V_{\text {space }} /\left(3600 \times 146 \times A_{\text {diffuser }}\right)$, where $V_{\text {space }}$ and $A_{\text {diffuser }}$ are the room volume and diffuser area, respectively, was applied to each inlet diffuser. At the return vent, an outflow uniform velocity with a mass flow rate equal to $80 \%$ of the inlet mass flow rate and a Neumann boundary condition for the temperature were assumed. The Neumann outflow boundary condition and no-slip boundary were applied to the exhaust vent and other surfaces, respectively. For occupant and lamp surfaces, a constant heat flux boundary condition (according to the data given in Section 5.1) was considered; for amphitheater walls and seats and pilasters, constant temperature boundary conditions (according to Table 3) and zero heat flux boundary conditions were implemented, respectively.

The considered objectives are thermal comfort indexes, PMV and PPD, local thermal comfort parameters, TGVD and $V_{M E A N}$, and energy saving, $E_{r}$. The

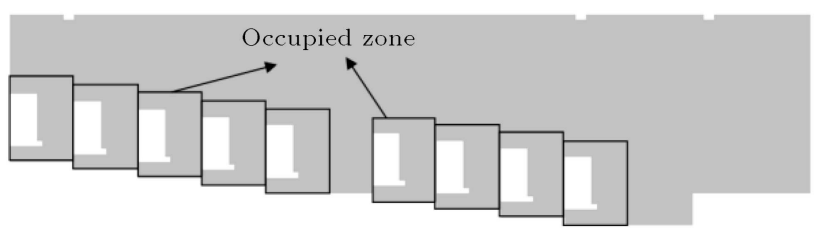

Figure 10. The occupied zone considered for the calculation of the objectives.

occupied zone used for the calculation of PMV and PPD indexes and $V_{M E A N}$ is shown in Figure 10. It includes 9 boxes, each of $10.2 \mathrm{~m}$ length (from $x=0.8 \mathrm{~m}$ to $x=11.1 \mathrm{~m}), 1.2 \mathrm{~m}$ width, and $1.5 \mathrm{~m}$ height from the floor surrounding the occupants.

\subsubsection{The Design Of Experiments (DOEs)}

Air change per hour, ACH, supply temperature, $T_{\text {sup }}$, and return air vent height, $h_{v e n t}$, are the three design variables considered here. The range of each parameter variation is chosen as follows: $\mathrm{ACH}$ varies from 5 to $35, T_{\text {sup }} 15$ to $25^{\circ} \mathrm{C}$, and $h_{\text {vent }} 0.6$ to $4 \mathrm{~m}$ (the elevations of the north wall). At the first step, i.e. DOE, 20 design points (simulation cases) are selected by the Optimal Space Filling (OSF) algorithm [43] such that the design points cover the whole range of design parameters effectively. These points, generated by OSF, are reported in Table 4.

For each of these 20 cases, a computational grid with about 3.41 million cells (like the one described in Section 5.1) was constructed and the numerical simulation with the LES model was carried out. Then, the objective parameters (defined in Section 3) were computed for each of these design points to be used at the next step.

Several measures can be used to show the quality of the grid used for the LES [44-46]. One of the most reliable assessments is the viscosity ratio, $\mu_{t} / \mu$, which is a measure of the modeled turbulence and the 
Table 4. The 20 design points chosen by the Design of Experiment (DOE) process.

\begin{tabular}{ccccccccccc}
\hline Case no. & $\mathbf{1}$ & $\mathbf{2}$ & $\mathbf{3}$ & $\mathbf{4}$ & $\mathbf{5}$ & $\mathbf{6}$ & $\mathbf{7}$ & $\mathbf{8}$ & $\mathbf{9}$ & $\mathbf{1 0}$ \\
\hline $\mathrm{ACH}(-)$ & 23.13 & 19.38 & 6.88 & 20.63 & 11.88 & 29.38 & 15.63 & 28.13 & 10.63 & 25.63 \\
$T_{\text {sup }}\left({ }^{\circ} \mathrm{C}\right)$ & 18.8 & 20 & 20.8 & 17.6 & 16 & 18.4 & 21.6 & 21.2 & 16.8 & 16.4 \\
$h_{\text {vent }}(\mathrm{m})$ & 4 & 0.7 & 1.2 & 1.7 & 3.6 & 2.5 & 3.7 & 1.4 & 0.85 & 1 \\
\hline Case no. & $\mathbf{1 1}$ & $\mathbf{1 2}$ & $\mathbf{1 3}$ & $\mathbf{1 4}$ & $\mathbf{1 5}$ & $\mathbf{1 6}$ & $\mathbf{1 7}$ & $\mathbf{1 8}$ & $\mathbf{1 9}$ & $\mathbf{2 0}$ \\
\hline ACH $(-)$ & 18.13 & 13.13 & 16.88 & 21.88 & 14.38 & 24.38 & 26.88 & 9.38 & 5.63 & 8.13 \\
$T_{\text {sup }}\left({ }^{\circ} \mathrm{C}\right)$ & 22.8 & 19.6 & 18 & 20.4 & 15.2 & 15.6 & 22 & 22.4 & 17.2 & 19.2 \\
$h_{\text {vent }}(\mathrm{m})$ & 1.5 & 1.9 & 2.9 & 2.4 & 2 & 3 & 3.2 & 2.7 & 2.2 & 3.4 \\
\hline
\end{tabular}

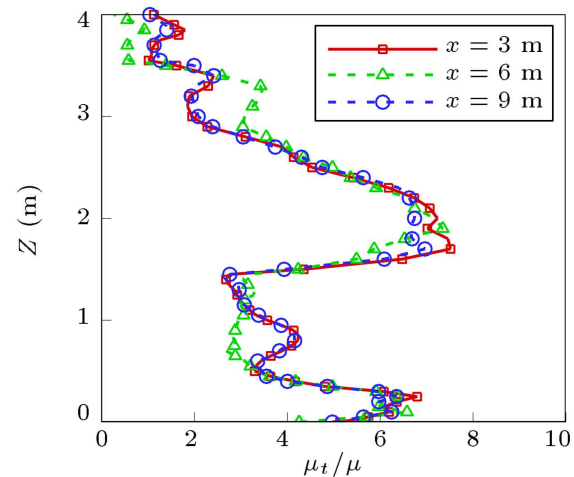

(a)

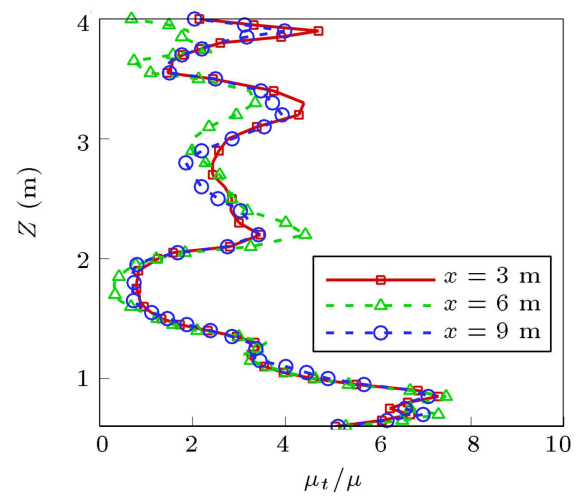

(c)

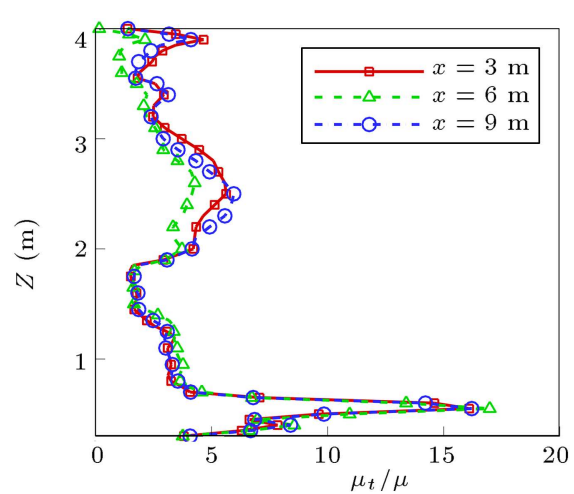

(b)

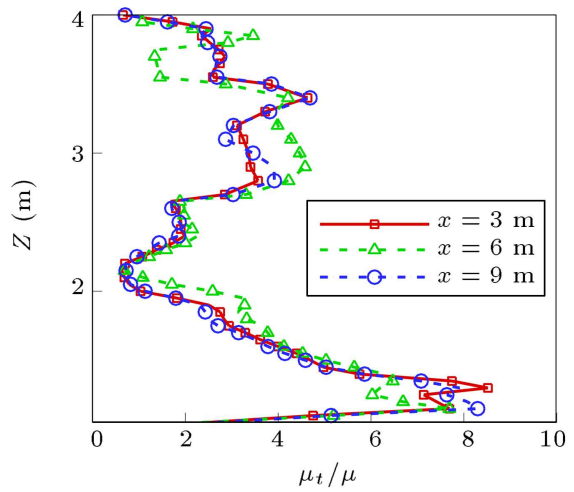

(d)

Figure 11. The viscosity ratio, $\mu_{t} / \mu$, profiles at different cross-sections of the amphitheater (Case no. 12 of Table 4): (a) $y=3.5 \mathrm{~m}$, (b) $y=6.3 \mathrm{~m}$, (c) $y=9.2 \mathrm{~m}$, and (d) $y=12.9 \mathrm{~m}$.

SGS diffusion introduced by LES with respect to the resolved turbulence. The value of viscosity ratio below 20 , which is associated with the LES index of quality greater than 0.8 [44], is regarded as the appropriate value of LES and is indicative of acceptable mesh quality [44]. The viscosity ratio profiles at 12 different cross-sections of the amphitheater are reported in Figure 11. As can be seen, the viscosity ratio is below 20 in all regions of the flow, advocating the high quality of the grid for the present simulations.

\subsubsection{The response surfaces}

At this step, a response surface was fitted with each ob- jective parameter versus the (three) design parameters using the data obtained in the previous section for the 20 design points. Herein, the non-parametric regression method [47] was applied to the response surface generation. Samples of the generated response surfaces are shown in Figure 12. Note that the response surfaces are functions of three variables and only to show them in the $3 \mathrm{D}$ physical space, the value of one parameter, say $h_{\text {vent }}$, is taken to be constant in this figure.

Before analyzing the responses, the quality of them was checked through the goodness of fit diagram, as shown in Figure 13. This diagram illustrates the exact values of the objectives obtained from the numer- 


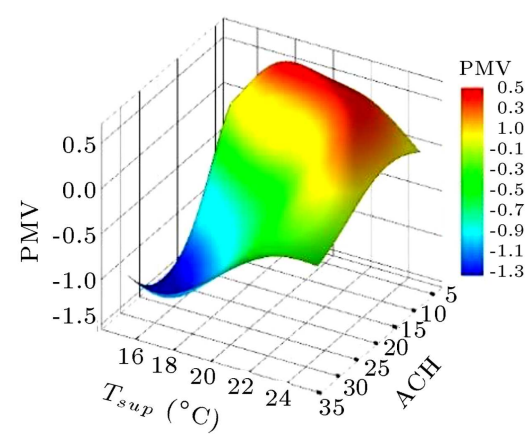

(a)

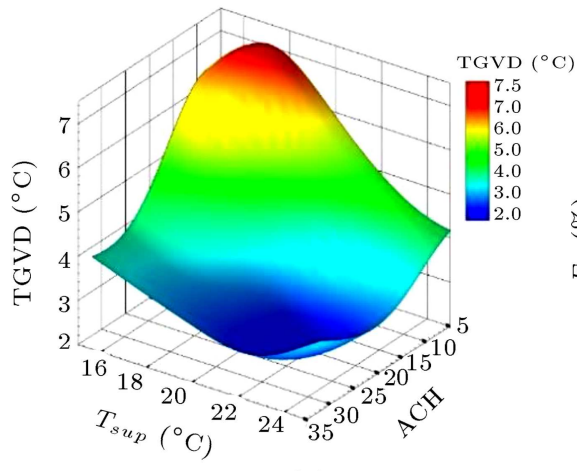

(b)

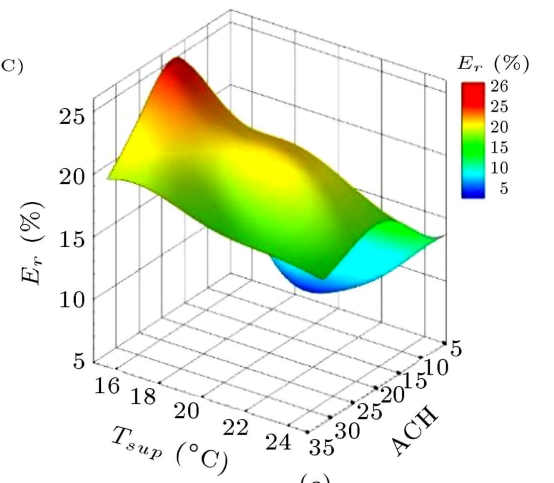

(c)

Figure 12. Samples of response surfaces in 3D space. The variation of (a) PMV index, (b) TGVD, and (c) $E_{r}$ versus $\mathrm{ACH}$ and $T_{\text {sup }}$ (at constant $h_{\text {vent }}$ of $2 \mathrm{~m}$ ).

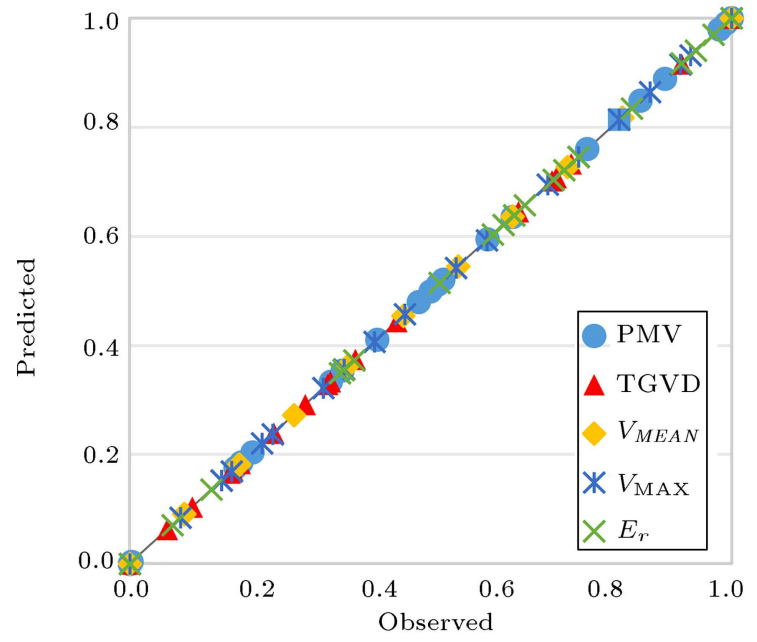

Figure 13. The goodness of fit diagram for the response surfaces. The predicted normalized values of objectives from the response surfaces versus their real (observed) value at the design points.

ical simulation of the design points versus the predicted values of objectives from the response surfaces at these points. In this diagram, the larger deviations of points from the line $x=y$ reflect the higher levels of error of response surfaces. According to Figure 13, the responses are accurate at least at design points.

Valuable information can be extracted from response surfaces. The sensitivity of objective parameters to design variables is a piece of this information. The sensitivity parameter, $r$, shows the degree of dependence of an objective on a design variable. The larger the magnitude of $r$, the stronger the dependence of the objective on a design variable. The positive and negative values of $r$ represent direct and inverse proportionalities, respectively. The local sensitivity of an objective parameter, $y$, to a design variable, $x$, can be defined as follows:

$$
r= \pm \frac{[\max (y)-\min (y)] /|\max (y)+\min (y)|}{[\max (x)-\min (x)] /|\max (x)+\min (x)|},
$$

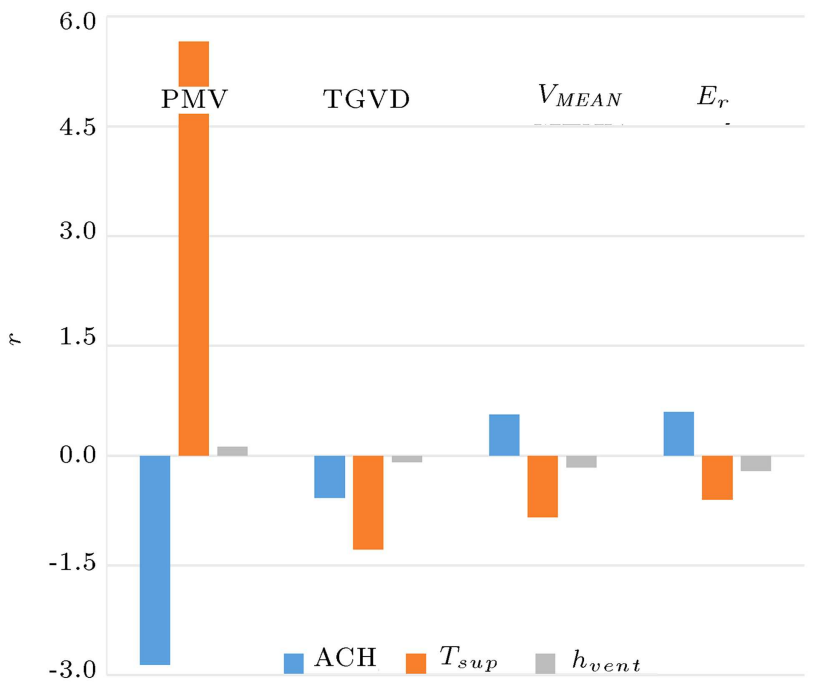

Figure 14. The local sensitivity, $r$, of the objective parameters to the design parameters.

where $\max ()$ and $\min ()$ functions represent the maximum and minimum values of $y=f(x)$ assuming all other design variables, except $x$, to be constant. The local sensitivity chart is reported in Figure 14. Based on these results, $T_{\text {sup }}$ is the most effective parameter influencing both global thermal comfort, PMV, local thermal comfort, TGVD, and $V_{M E A N}$ condition, while $T_{\text {sup }}$ and $\mathrm{ACH}$ are both effective parameters for the energy saving.

On average, increasing $T_{\text {sup }}$ raises the value of PMV significantly and decreases the other objectives, i.e., TGVD, $V_{M E A N}$, and $E_{r}$. On the other hand, when ACH grows, PMV and TGVD are reduced, while $V_{M E A N}$ and $E_{r}$ rise on average since the local sensitivity of $V_{M E A N}$ and $E_{r}$ upon $\mathrm{ACH}$ is negative, according to Figure 14. Moreover, with an increase in the height of the return vent, $h_{v e n t}$, the value of PMV increases and the other objectives, especially the energy saving, are reduced.

The response curves that are the projections of 


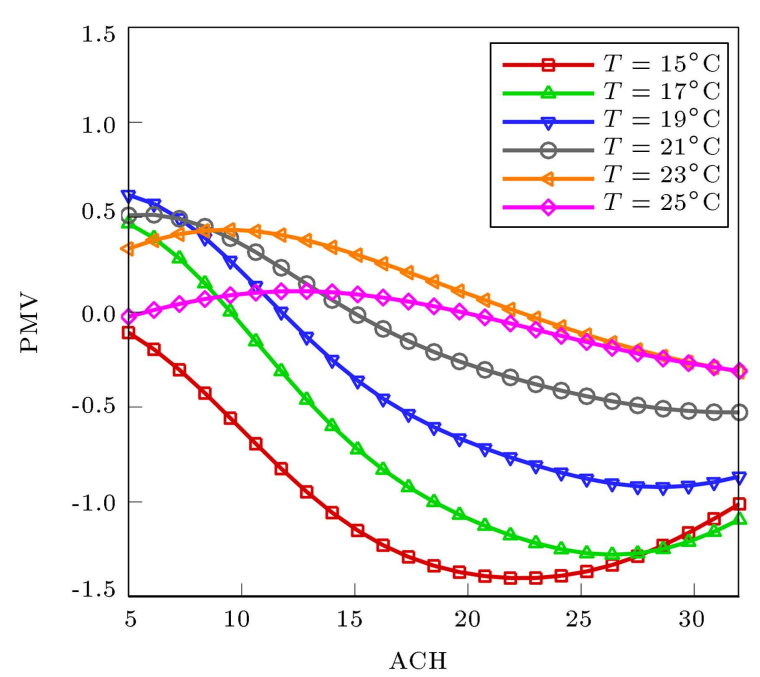

(a)

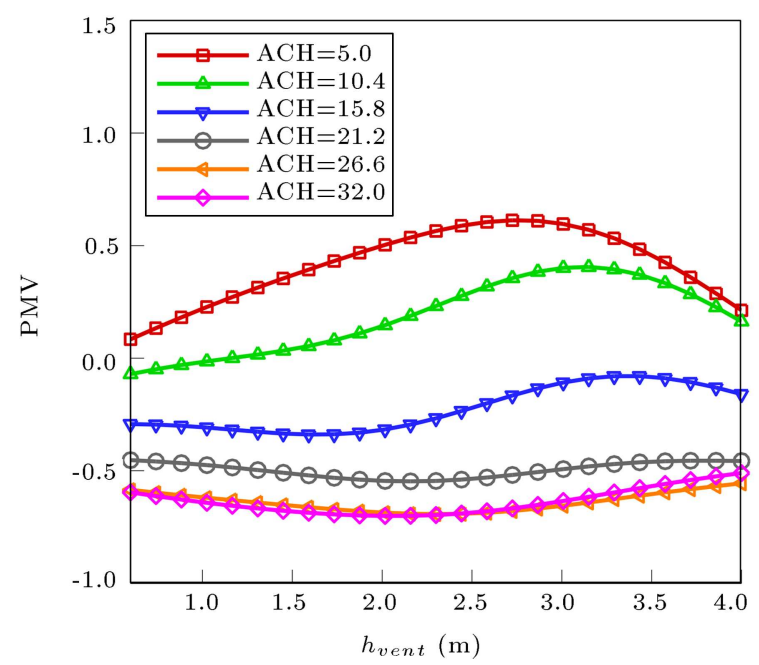

(b)

Figure 15. Response curves: The variation of Perdict Mean Vote (PMV) index versus: (a) Air Changes per Hour (ACH) for different values of the supply temperature and at the return air vent height of $2.3 \mathrm{~m}$, (b) the return air vent height for different values of $\mathrm{ACH}$ and at a supply temperature of $20^{\circ} \mathrm{C}$.

a response surface onto a $2 \mathrm{D}$ space can be used to investigate the details of the change of each objective parameter with the variation of the design variables. Figure 15 to Figure 18 show the response curves for different objectives as functions of design variables. According to Figure 15(a), for $A C H<10$, regardless of the $T_{\text {sup }}$ value, PMV magnitude, $|P M V|$, is below 0.5 . For $A C H>10$ and $T_{\text {sup }}<19^{\circ} \mathrm{C}$, PMV magnitude rises sharply by an increase in $A C H$ and this rise is more intense for smaller $T_{\text {sup }}$ values. This is due to the sense of coldness arising from the increase of the air flow rate at low supply air temperatures. Based on Figure 15(b), most conditions satisfy the criterion of $|P M V|<0.5$. Only a limited range of $A C H>26.6$ violates this criterion by a small amount.

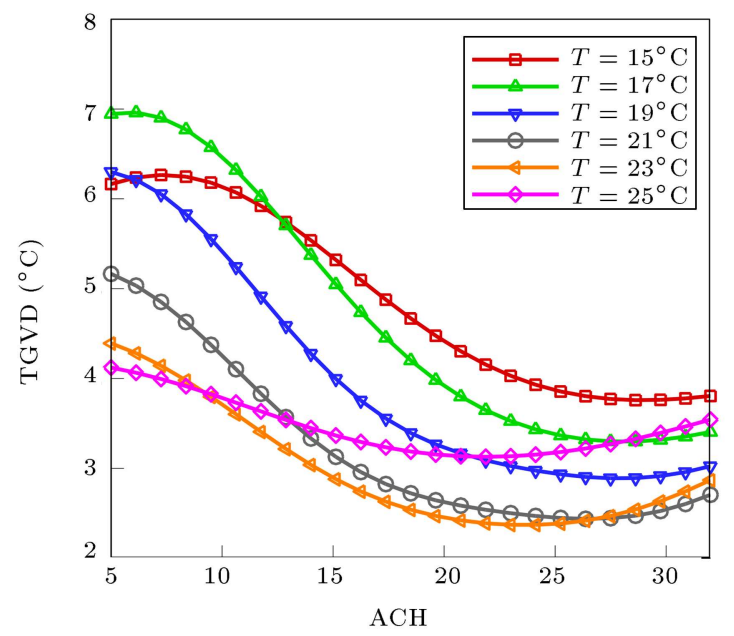

(a)

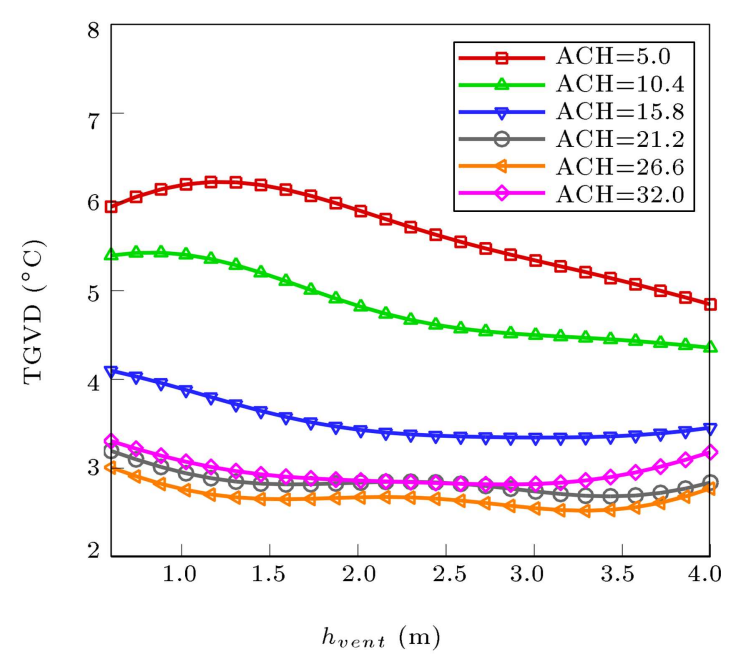

(b)

Figure 16. Response curves: The variation of TGVD versus: (a) Air Changes per Hour (ACH) for different values of the supply temperature and at a return air vent height of $2.3 \mathrm{~m}$ and (b) the return air vent height for different values of $\mathrm{ACH}$ and at a supply temperature of $20^{\circ} \mathrm{C}$.

Figure 16(a) shows that TGVD declines with an increase in $\mathrm{ACH}$ regardless of the value of $T_{\text {sup }}$. Only a range with $19^{\circ} \mathrm{C}<T_{\text {sup }}<24^{\circ} \mathrm{C}$ and $15<A C H<30$ is in the allowable range $\left(T G V D<3^{\circ} \mathrm{C}\right)$ for this height. Based on Figure 16(b), for $A C H>10$, the variation of the temperature gradient in the vertical direction with the change in $h_{v e n t}$ is insignificant. This result is consistent with the finding by Lin and Tsai [11]. However, for low ACH $(A C H<10)$, TGVD increases with a reduction in the vent height. This is due to the rise of the room air temperature in upper layers as a consequence of the escape of fresh cold air from the return vent when $h_{v e n t}$ is reduced (short circuit effect).

According to Figure 17, $V_{M E A N}$ increases as $\mathrm{ACH}$ grows in the allowable range $(<0.8 \mathrm{~m} / \mathrm{s})$ in all 


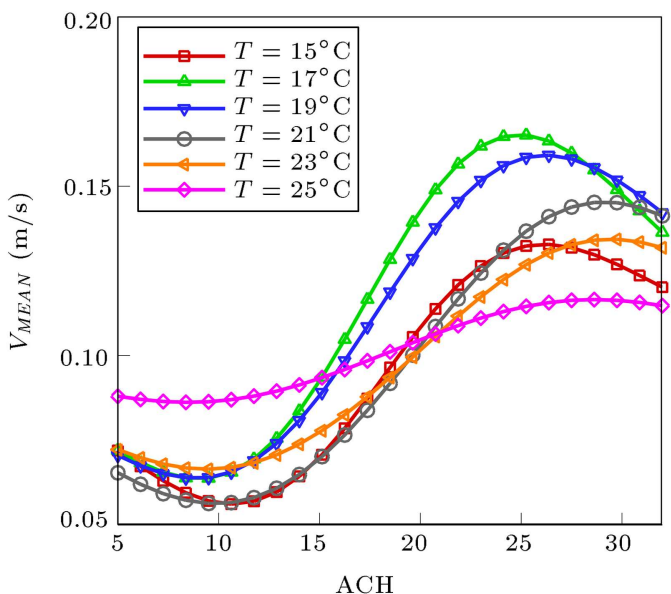

(a)

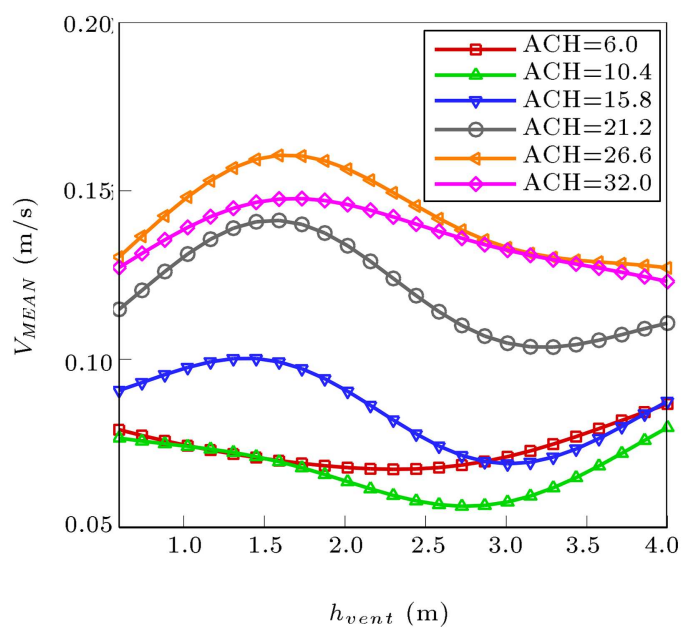

(b)

Figure 17. Response curves: The variation of $V_{M E A N}$ versus: (a) Air Changes per Hour (ACH) for different values of the supply temperature and at a return air vent height of $2.3 \mathrm{~m}$ and (b) the return air vent height for different values of $\mathrm{ACH}$ and at a supply temperature of $20^{\circ} \mathrm{C}$.

operating conditions. The variation of $V_{M E A N}$ with $h_{\text {vent }}$ is minor at a specific $\mathrm{ACH}$ value.

Figure 18 illustrates the variation of the energy saving parameter. The maximum energy saving at all $T_{\text {sup }}$ values occurs at about $A C H=18$ (Figure $18(\mathrm{a})$ ). At this local optimum $\mathrm{ACH}$ value, $E_{r}$ also increases with the growth of $T_{\text {sup }}$. However, at large ACHs, the variation of $E_{r}$ with changes in $T_{\text {sup }}$ is significantly reduced, i.e., the effect of air supply temperature on energy saving wears off at high $\mathrm{ACH}$ values. This response indicates that at about $\mathrm{ACH} \sim 18, T_{\text {sup }}=$ $15^{\circ} \mathrm{C}$, and $h_{\text {vent }}=2.3 \mathrm{~m}$, an energy saving rate as large as $25 \%$ is achievable. However, this condition results in thermal discomfort as can be seen in Figure 15 (PMV -1.3) and for the best design, a multiobjective optimization should be carried out (the next section). For $A C H>10$, the lower return vent heights

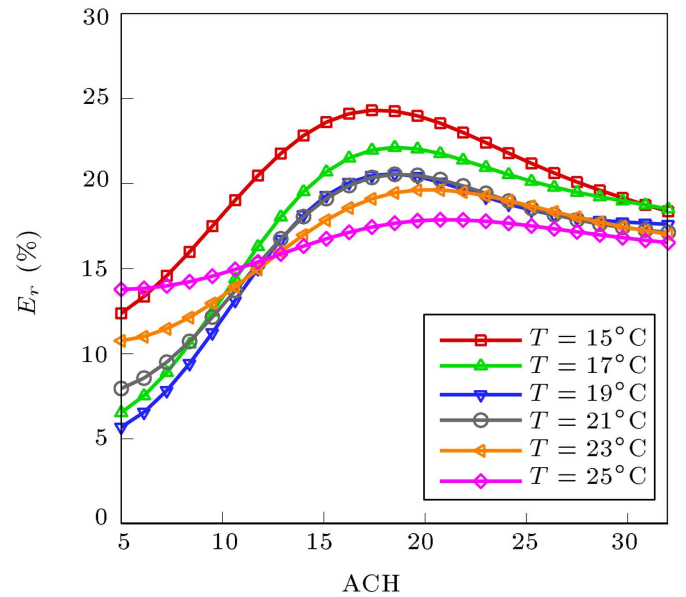

(a)

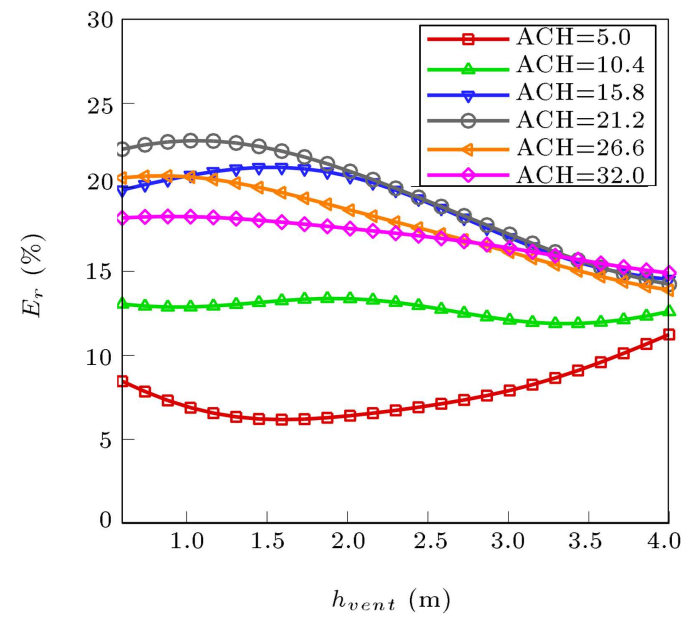

(b)

Figure 18. Response curves: The variation of $E_{r}$ versus (a) Air Changes per Hour (ACH) for different values of the supply temperature and at a return air vent height of $2.3 \mathrm{~m}$ and (b) the return air vent height for different values of $\mathrm{ACH}$ and at a supply temperature of $20^{\circ} \mathrm{C}$.

bring about a higher amount of energy saving (Figure $18(\mathrm{~b})$ ), which is in agreement with the result reported by Fan et al. [10]. According to Figure 18(b), the effect of $\mathrm{ACH}$ on $E_{r}$ is more pronounced for smaller $h_{v e n t}$ values.

The next valuable information is finding the cases (designs) with the maximum or minimum value of a specific objective. This is accomplished by finding the maximum or minimum of a response surface (singleobjective optimization). The important maximums and minimums are reported in Table 5. According to the first and second rows of the table, a design with the PMV near zero (PPD 5\%) and a design with the PMV as large as -1.4 (PPD 46\%) are possible in the range of this study. Moreover, it can be seen that the response surfaces include designs with a wide range of TGVDs from 2.18 to $7.13^{\circ} \mathrm{C}$ and $E_{r}$ ranging from 5.33 to $25.21 \%$. 
Table 5. Important minimums/maximums of response surfaces.

\begin{tabular}{|c|c|c|c|c|c|c|c|c|}
\hline \multirow[b]{2}{*}{$\begin{array}{l}\text { Minimum/ } \\
\text { maximum }\end{array}$} & \multicolumn{3}{|c|}{ Design parameters } & \multicolumn{5}{|c|}{ Objective values } \\
\hline & $\begin{array}{c}\mathrm{ACH} \\
(-)\end{array}$ & $\begin{array}{l}T_{\text {sup }} \\
\left({ }^{\circ} \mathrm{C}\right)\end{array}$ & $\begin{array}{c}h_{\text {vent }} \\
(\mathrm{m})\end{array}$ & $\begin{array}{c}\text { PMV } \\
(-)\end{array}$ & $\begin{array}{c}\text { PPD } \\
(\%)\end{array}$ & $\begin{array}{c}\text { TGVD } \\
\left({ }^{\circ} \mathrm{C}\right)\end{array}$ & $\begin{array}{l}V_{M E A N} \\
(\mathrm{~m} / \mathrm{s})\end{array}$ & $\begin{array}{c}E_{r} \\
(\%)\end{array}$ \\
\hline Minimum $|P M V|(-)$ & 22.18 & 24.21 & 2.34 & 0.0005 & 5.00 & 2.77 & 0.112 & 18.51 \\
\hline Maximum $|P M V|(-)$ & 22.98 & 15.36 & 2.46 & -1.4134 & 46.2 & 3.95 & 0.1315 & 21.8 \\
\hline Minimum TGVD & 25.73 & 21.92 & 3.18 & -0.263 & 6.44 & 2.18 & 0.127 & 17.44 \\
\hline Maximum TGVD & 6.44 & 17.03 & 1.65 & 0.2076 & 5.89 & 7.13 & 0.0693 & 9.184 \\
\hline Minimum $V_{M E A N}$ & 10.64 & 20.98 & 2.68 & 0.396 & 8.27 & 4.0 & 0.054 & 13.46 \\
\hline Maximum $V_{M E A N}$ & 23.93 & 17.84 & 1.71 & -1.077 & 29.47 & 3.3 & 0.1813 & 21.56 \\
\hline Minimum $E_{r}$ & 5 & 18.19 & 2.4 & 0.629 & 13.3 & 6.65 & 0.0723 & 5.33 \\
\hline Maximum $E_{r}$ & 17.87 & 15.0 & 1.84 & -1.267 & 38.58 & 4.88 & 0.096 & 25.21 \\
\hline
\end{tabular}

Table 6. The definition of different Multi-Objective Optimizations (MOOs) performed in this study.

\begin{tabular}{llc}
\hline MOO & \multicolumn{1}{c}{ Goals } & Constraints \\
\hline No. 1 & Min. $|P M V|$, Min. TGVD, and Min. $V_{M E A N}$ & - \\
No. 2 & Max. $E_{r}$ & $-0.5<P M V<0.5, T G V D<3{ }^{\circ} \mathrm{C}$, and $V_{M E A N}<0.8 \mathrm{~m} / \mathrm{s}$ \\
\hline
\end{tabular}

Table 7. The best candidates of different Multi-Objective Optimizations (MOOs).

\begin{tabular}{|c|c|c|c|c|c|c|c|c|c|}
\hline \multirow[b]{2}{*}{ MOO } & \multicolumn{3}{|c|}{ Design parameters } & \multicolumn{6}{|c|}{ Objective values } \\
\hline & $\begin{array}{c}\text { ACH } \\
(-)\end{array}$ & $\begin{array}{l}T_{\text {sup }} \\
\left({ }^{\circ} \mathrm{C}\right)\end{array}$ & $\begin{array}{c}h_{\text {vent }} \\
(\mathrm{m})\end{array}$ & $\begin{array}{c}\text { PMV } \\
(-)\end{array}$ & $\begin{array}{c}\text { PPD } \\
(\%)\end{array}$ & $\begin{array}{c}\text { TGVD } \\
\left({ }^{\circ} \mathrm{C}\right)\end{array}$ & $\begin{array}{l}V_{M E A N} \\
(\mathrm{~m} / \mathrm{s})\end{array}$ & $\begin{array}{l}V_{\max } \\
(\mathrm{m} / \mathrm{s})\end{array}$ & $\begin{array}{c}E_{r} \\
(\%)\end{array}$ \\
\hline \multirow[t]{3}{*}{ No. 1} & 15.96 & 20.8 & 3.07 & 0.002 & 5.00 & 3.05 & 0.0682 & 0.4873 & 17.42 \\
\hline & 17.22 & 22.02 & 3.34 & 0.031 & 5.02 & 2.71 & 0.0813 & 0.4919 & 17.95 \\
\hline & 19.49 & 21.89 & 2.61 & -0.06 & 5.07 & 2.5 & 0.092 & 0.625 & 19.46 \\
\hline \multirow[t]{3}{*}{ No. 2} & 20.07 & 20.19 & 1.16 & -0.411 & 8.52 & 2.93 & 0.1256 & 0.5998 & 22.9 \\
\hline & 19.94 & 20.33 & 1.19 & -0.376 & 7.94 & 2.88 & 0.123 & 0.5977 & 22.9 \\
\hline & 20.07 & 20.33 & 1.19 & -0.379 & 8.00 & 2.86 & 0.1239 & 0.6022 & 22.9 \\
\hline
\end{tabular}

\subsubsection{The Multi-Objective Optimizations (MOOs)}

To find optimal designs, two sets of goals corresponding to two separate MOOs are considered in this section. From one point of view, to achieve the best global and local thermal comfort conditions, the magnitudes of the PMV index, TGVD, and $V_{M E A N}$ are minimized simultaneously (MOOs no. 1). From the second point of view, only energy saving, $E_{r}$, is maximized while the values of the global and local thermal comfort parameters satisfy the criteria imposed by the ISO7730 standard, i.e. $|P M V|<0.5|P M V|<0.5, T G V D<$ $3^{\circ} \mathrm{C}$, and $V_{M E A N}<0.8 \mathrm{~m} / \mathrm{s}$ (MOO no. 2). These two MOOs are summarized in Table 6. Here, the MOOs were performed by the Non-dominated Sorting Genetic Algorithm II (NSGA II) [48] based on the response surfaces generated in the previous section. The optimal designs including the three best design candidates of each optimization are reported in Table 7 .

According to Table 7 , for MOO no. 1, a very small PMV index of about 0.002 (corresponding to PPD of $5.00 \%)$ is attainable, while both $V_{M E A N}$ and $V_{\max }$ in the occupant zone are below $0.8 \mathrm{~m} / \mathrm{s}$ and TGVD is about $3{ }^{\circ} \mathrm{C}$ (the first row of Table 7 ). For this design, $A C H=15.96, T_{\text {sup }}=20.8^{\circ} \mathrm{C}$, and $h_{\text {vent }}=3.07 \mathrm{~m}$. This case corresponds to the best global and local thermal comfort condition. However, the energy saving for this case is $E_{r}=17.42 \%$. To achieve higher energy saving while the thermal comfort complies with the ISO7730 standard, the best candidates of MOO no. 2 can be considered. The best candidate characterized by $A C H=20.07, T_{\text {sup }}=20.19^{\circ} \mathrm{C}$, and $h_{\text {vent }}=1.16 \mathrm{~m}$ has nearly the same $T_{\text {sup }}$ as the previously mentioned optimal condition, but with a larger $\mathrm{ACH}$ and smaller $h_{\text {vent }}$. With this new optimal design, the energy saving is as large as $22.9 \%$ while keeping the local and global thermal comfort measures in the allowable range. This case was proposed as the best design in this study. It should be noted that in terms of the mean air velocity within the occupant zone, $V_{M E A N}$, all the proposed optimal cases in Table 7 meet the more stringent standards like ISO EN7730 with the allowable $V_{M E A N}$ within the range of 0.1 to $0.3 \mathrm{~m} / \mathrm{s}$. 


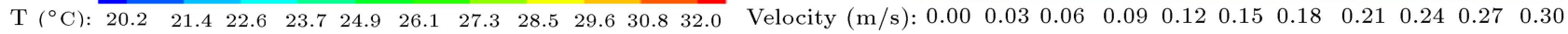
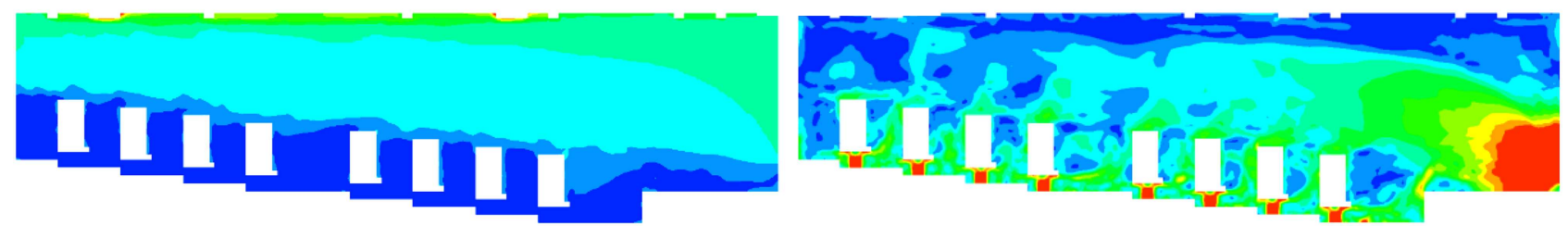

Figure 19. The instantaneous temperature and velocity contours on the central XY plane for the best design: $A C H=20.7, T_{\text {sup }}=20.19, h_{\text {vent }}=1.16$ (MOO no. 2$)$.

Table 8. Objectives' values obtained from the original response surfaces and from new simulations for the verification point.

\begin{tabular}{|c|c|c|c|c|c|c|c|c|c|}
\hline & \multicolumn{3}{|c|}{ Design parameters } & \multicolumn{6}{|c|}{ Objective values } \\
\hline & $\begin{array}{c}\mathrm{ACH} \\
(-)\end{array}$ & $\begin{array}{l}T_{\text {sup }} \\
\left({ }^{\circ} \mathrm{C}\right)\end{array}$ & $\begin{array}{c}h_{\text {vent }} \\
(\mathrm{m})\end{array}$ & $\begin{array}{c}\text { PMV } \\
(-)\end{array}$ & $\begin{array}{c}\text { PPD } \\
(\%)\end{array}$ & $\begin{array}{c}\text { TGVD } \\
\left({ }^{\circ} \mathrm{C}\right)\end{array}$ & $\begin{array}{l}V_{M E A N} \\
(\mathrm{~m} / \mathrm{s})\end{array}$ & $\begin{array}{c}V_{\min } \\
(\mathrm{m} / \mathrm{s})\end{array}$ & $\begin{array}{c}E_{r} \\
(\%) \\
\end{array}$ \\
\hline Simulation & 20.07 & 20.19 & 1.16 & -0.418 & 8.64 & 3.12 & 0.1117 & 0.561 & 22.17 \\
\hline Response & 20.07 & 20.19 & 1.16 & -0.411 & 8.52 & 2.93 & 0.1256 & 0.5998 & 22.9 \\
\hline Error $(\%)$ & - & - & - & 1.7 & 1.3 & 6 & 12 & 6 & 3.2 \\
\hline
\end{tabular}

To further validate our optimization results and the quality of response surfaces used for the optimization, in addition to the goodness of fit diagram presented in Figure 13, the best design obtained from MOO no. 2 is simulated using the LES approach (Section 2). The results, the contours of velocity and temperature, of this simulation are illustrated in Figure 19, and the objectives are directly computed by the post-processing of the results of the simulations. In Table 8 , the values obtained from the simulations are compared with those predicted by the response surfaces. The low values of the relative errors of the response surfaces for this verification point indicate the accuracy and reliability of the generated responses.

\section{Conclusion}

In this work, a Computational Fluid Dynamics (CFD) model based on the Large Eddy Simulation (LES) closure was introduced and validated against experimental data. Then, this model was used to study the effect of various design parameters including the Air Changes per Hour $(\mathrm{ACH})$, supply air temperature $\left(T_{\text {sup }}\right)$, and return air vent height $\left(V_{M E A N}\right)$ on the performance objectives, namely the global (PMV or PPD) and local (TGVD and $V_{M E A N}$ ) thermal comfort measures and energy saving parameter $\left(E_{r}\right)$, of an amphitheater equipped with a Under-Floor Air Distribution (UFAD) system. A systematic multi-objective optimization approach comprising a design of experiments, response surface generation and analyses, and optimization steps was adopted for this study. The main findings of this work can be summarized as follows:
- Based on the sensitivity analysis, the global and local thermal comfort indexes were most sensitive to $T_{\text {sup }}$ while the energy saving was sensitive to $\mathrm{ACH}$ and $T_{\text {sup }}$ to the same extent. $h_{v e n t}$ influenced $E_{r}$ more than other objectives;

- For $A C H>10$ and $T_{\text {sup }}<19^{\circ} \mathrm{C}$, Predicted Mean Vote (PMV) magnitude rose sharply following the growth of $\mathrm{ACH}$;

- For low $A C H(A C H<10)$, Temperature Gradient in Vertical Direction (TGVD) increased with a reduction in $h_{v e n t}$ due to the short circuit effect, i.e., the rise of room temperature in upper layers as the result of the escape of fresh cold air from the lowheight return vent. However, for the larger values of $\mathrm{ACH}(A C H>10)$, TGVD was found insensitive to $h_{\text {vent }}$, which was in agreement with the findings of previous studies;

- $V_{M E A N}<0.8 \mathrm{~m} / \mathrm{s}$ was a less stringent criterion satisfied by almost all the range of design points in our study;

- For $A C H>10$, lower $h_{\text {vent }}$ resulted in higher energy saving. At a low $h_{v e n t}$, the effect of $\mathrm{ACH}$ on $E_{r}$ was more pronounced;

- Based on the multi-objective optimization, the design with $A C H \sim 20, \quad T_{\text {sup }} \sim 20.2^{\circ} \mathrm{C}$, and $h_{\text {vent }} / h_{\text {space }} \sim 0.3$, where $h_{\text {space }}$ is the height of the space, brought about an optimal condition with the global and local thermal comfort indexes within the allowable range and $E_{r}$ as large as $22.9 \%$. 


\section{Acknowledgement}

This work was supported by the High-Performance Computing Research Center (HPCRC)-Amirkabir University of Technology under Contract No. ISI-DCEDOD-Cloud-900808-1700.

\section{References}

1. Haines, R.W. and Hittle, D.C., Control Systems for Heating, Ventilating, and Air Conditioning: Springer Sci. Bus. Media (2006).

2. Eslami, J., Abbassi, A., and Saidi, M. "Numerical simulation of the effect of visitor's movement on bacteria-carrying particles distribution in hospital isolation room", Scientia Iranica., Trans., B, Mech. Eng., 24(3), pp. 1160-1170 (2017).

3. Bauman, F. and Webster, T. "Outlook for underfloor air distribution", ASHRAE J., 43(6), p. 18 (2001).

4. Lin, Z., Chow, T., Fong, K., et al. "Comparison of performances of displacement and mixing ventilations. Part I: thermal comfort", Int. J. Refrig, 28(2), pp. 276-287 (2005).

5. Lin, Z., Chow, T., Fong, K., et al. "Comparison of performances of displacement and mixing ventilations. Part II: indoor air quality", Int. J. Refrig, 28(2), pp. 288-305 (2005).

6. Lin, Z., Chow, T., Tsang, C., et al. "CFD study on effect of the air supply location on the performance of the displacement ventilation system", Build Environ, 40(8), pp. 1051-1067 (2005).

7. Chung, J.D., Hong, H., and Yoo, H. "Analysis on the impact of mean radiant temperature for the thermal comfort of underfloor air distribution systems", Energy Build, 42(12), pp. 2353-2359 (2010).

8. Alajmi, A. and El-Amer, W. "Saving energy by using underfloor-air-distribution (UFAD) system in commercial buildings", Energy Convers. Manage, 51(8), pp. 1637-1642 (2010).

9. Xu, H., Gao, N., and Niu, J. "A method to generate effective cooling load factors for stratified air distribution systems using a floor-level air supply", HVAC Res., 15(5), pp. 915-930 (2009).

10. Fan, Y., Li, X., Yan, Y., et al. "Overall performance evaluation of underfloor air distribution system with different heights of return vents", Energy Build, 147, pp. 176-187 (2017).

11. Lin, Y. and Tsai, T. "An experimental study on a fullscale indoor thermal environment using an under-floor air distribution system", Energy Build, 80, pp. 321330 (2014).

12. Peng, P., Gong, G., Mei, X., et al. "Investigation on thermal comfort of air carrying energy radiant airconditioning system in south-central China", Energy Build, 182, pp. 51-60 (2019).
13. Cao, S.-J. and Deng, H.-Y. "Investigation of temperature regulation effects on indoor thermal comfort, air quality, and energy savings toward green residential buildings", Sci. Technol. Built Environ, 25(3), pp. 113 (2019).

14. Stamou, A. and Katsiris, I. "Verification of a CFD model for indoor airflow and heat transfer", Built Environ, 41(9), pp. 1171-1181 (2006).

15. Talatahari, S., Hakimpour, F., and Ranjbar, A. "Application of multi-objective charged system search algorithm for optimization problems", Scientia Iranica, 26(3), pp. 1249-1265 (2019).

16. Sotoudeh-Anvari, A., Sadjadi, S.J., Molana, S.M.H., et al. "A stochastic multi-objective model based on the classical optimal search model for searching for the people who are lost in response stage of earthquake", Scientia Iranica, 26(3), pp. 1842-1864 (2019).

17. Alikhani-Kooshkak, R., Tavakkoli-Moghaddam, R., Jamili, A., et al. "Multi-objective mathematical modeling of an integrated train makeup and routing problem in an Iranian railway company", Scientia Iranica, (In press).

18. Shan, X., Xu, W., Lee, Y.-K., et al. "Evaluation of thermal environment by coupling CFD analysis and wireless-sensor measurements of a full-scale room with cooling system", Sustainable Cities and Soc, 45, pp. 395-405 (2019).

19. Ahmed, A.Q. and Gao, S. "Numerical investigation of height impact of local exhaust combined with an office work station on energy saving and indoor environment", Build. Environ, 122, pp. 194-205 (2017).

20. Zhang, K., Zhang, X., Li, S., et al. "Experimental parametric study on the temperature distribution of an underfloor air distribution (UFAD) system with grille diffusers", Indoor Built Environ, 25(5), pp. 748-757 (2016).

21. Nada, S., El-Batsh, H., Elattar, H., et al. "CFD investigation of airflow pattern, temperature distribution and thermal comfort of UFAD system for theater buildings applications", J. Build. Eng., 6, pp. 274-300 (2016).

22. Alajmi, A.F., Baddar, F.A., and Bourisli, R.I. "Thermal comfort assessment of an office building served by under-floor air distribution (UFAD) system-A case study", Build. Environ, 85, pp. 153-159 (2015).

23. Alajmi, A.F., Abou-Ziyan, H.Z., and El-Amer, W. "Energy analysis of under-floor air distribution (UFAD) system: An office building case study", Energy Convers Manage, 73, pp. 78-85 (2013).

24. Kim, G., Schaefer, L., Lim, T. S., et al. "Thermal comfort prediction of an underfloor air distribution system in a large indoor environment", Energy Build, 64, pp. 323-331 (2013).

25. Fong, M., Lin, Z., Fong, K., et al. "Evaluation of thermal comfort conditions in a classroom with three ventilation methods", Indoor Air, 21(3), pp. 231-239 (2011). 
26. Lin, Z., Chow, T.T., Tsang, C., et al. "Effect of internal partitions on the performance of under floor air supply ventilation in a typical office environment", Build. Environ, 44(3), pp. 534-545 (2009).

27. Awad, A., Calay, R., Badran, O., et al. "An experimental study of stratified flow in enclosures", Appl. Therm. Eng., 28(17), pp. 2150-2158 (2008).

28. Lin, Y.-J.P. and Linden, P. "A model for an under floor air distribution system", Energy Build, 37(4), pp. 399409 (2005).

29. Wan, M. and Chao, C. "Numerical and experimental study of velocity and temperature characteristics in a ventilated enclosure with underfloor ventilation systems", Indoor Air, 15(5), pp. 342-355 (2005).

30. Rodi, W., Turbulent Buoyant Jets and Plumes, 3: Pergamon press Oxford (1982).

31. McGrattan, K.B., Baum, H.R., Rehm, R.G., et al., Fire Dynamics Simulator-Technical Reference Guide, National Institute of Standards and Technology, Building and Fire Research Laboratory (2000).

32. Stephen, B., Pope Turbulent Flows, Ed: Cambridge University Press, Cambridge (2000).

33. Deardorff, J.W. "Stratocumulus-capped mixed layers derived from a three-dimensional model", Boundary Layer Meteorol, 18(4), pp. 495-527 (1980).

34. Wilcox, D.C., Turbulence Modeling for CFD, 2: DCW industries La Canada, CA (1998).

35. Chase, M.W. "NIST-JANAF thermochemical tables", 4th Ed., J. Phys. Chem. Ref. Data, Monograph 9 (1999).

36. Fanger, P.O., Thermal comfort. Analysis and Applications in Environmental Engineering, Danish Technical Press, Copenhagen (1970).

37. Fanger, P. "Moderate thermal environments determination of the PMV and PPD indices and specification of the conditions for thermal comfort", ISO 7730 (1984).

38. ASHRAE Handbook, Fundamentals, American Society of Heating, Refrigerating and Air Conditioning Engineers, Atlanta, 111 (2001).

39. Cheng, Y., Niu, J., and Gao, N. "Stratified air distribution systems in a large lecture theatre: A numerical method to optimize thermal comfort and maximize energy saving", Energy Build., 55, pp. 515525 (2012).

40. Roe, P.L. "Characteristic-based schemes for the Euler equations", Annu. Rev. Fluid Mech., 18(1), pp. 337365 (1986).

41. Available: https://pages.nist.gov/fds-smv/index.html

42. Loomans, M., The Measurement and Simulation of Indoor Air Flow, University of Eindhoven (1998).
43. Pronzato, L. and Müller, W.G. "Design of computer experiments: space filling and beyond", Stat. Comput, 22(3), pp. 681-701 (2012).

44. Celik, I., Cehreli, Z., and Yavuz, I. "Index of resolution quality for large eddy simulations", J. Fluids Eng., 127(5), pp. 949-958 (2005).

45. Sardasht, M.T., Hosseini, R., and Amani, E. "An analysis of turbulence models for prediction of forced convection of air stream impingement on rotating disks at different angles", Int. J. Therm. Sci., 118, pp. 139151 (2017).

46. Safavi, M. and Amani, E. "A comparative study of turbulence models for non-premixed swirl-stabilized flames", J. Turbul., 19(11-12), pp. 1017-1050 (2018).

47. Lin, Y. and Zhang, H.H. "Component selection and smoothing in multivariate nonparametric regression", Ann. Stat., 34(5), pp. 2272-2297 (2006).

48. Deb, K., Pratap, A., Agarwal, S., et al. "A fast and elitist multiobjective genetic algorithm: NSGA-II", IEEE Trans. Evol. Comput., 6(2), pp. 182-197 (2002).

\section{Biographies}

Rahman Rahmaninia graduated with an MSc degree in Mechanical Engineering from Amirkabir University of Technology (Tehran polytechnic) in 2017. He was graduated with BSc degree in Mechanical Engineering from Shahid Bahonar University of Kerman in 2014. His main research interest is in modern ventilation systems.

Ehsan Amani is an Assistant Professor at Mechanical Engineering Department of Amirkabir University of Technology (Tehran polytechnic). He received his $\mathrm{PhD}$ in Mechanical Engineering from Amirkabir University, Tehran, Iran in 2012. His main area of research is Computational Fluid Dynamics (CFD), especially in multiphase and/or turbulent flows. He is currently working on turbulent and multiphase flow engineering systems and emission reduction of the combustion chambers of industrial gas turbines and internal combustion engines.

Abbas Abbassi is a Professor at the Mechanical Engineering Department of Amirkabir University of Technology (Tehran polytechnic). He received his $\mathrm{PhD}$ in Mechanical Engineering from B'ham University in 1989. His main area of research is concentrated on convection heat transfer and HVAC system design. Also, he is PEng and member of ASHRAE and ISME societies. 